\title{
Protecting and rescuing the effectors: roles of differentiation and survival in the control of memory T cell development
}

\section{Sema Kurtulus, Pulak Tripathi and David A. Hildeman*}

Division of Cellular and Molecular Immunology, Department of Pediatrics, Cincinnati Children's Hospital Medical Center, University of Cincinnati, Cincinnati, $\mathrm{OH}$, USA

\section{Edited by:}

Gabrielle Belz, Walter and Eliza Hall Institute of Medical Research,

Australia

\section{Reviewed by:}

Paul Klenerman, University of Oxford, UK

Laura K. Mackay, University of

Melbourne, Australia

\section{*Correspondence:}

David A. Hildeman, Division of Cellular and Molecular Immunology,

Department of Pediatrics, Cincinnati Children's Hospital Medical Center, University of Cincinnati, S5.Rm 214, MLC 7038, 3333 Burnet Avenue,

Cincinnati, OH 45229, USA.

e-mail:david.hildeman@cchmc.org
Vaccines, arguably the single most important intervention in improving human health, have exploited the phenomenon of immunological memory. The elicitation of memory $T$ cells is often an essential part of successful long-lived protective immunity. Our understanding of T cell memory has been greatly aided by the development of TCR Tg mice and MHC tetrameric staining reagents that have allowed the precise tracking of antigen-specific $T$ cell responses. Indeed, following acute infection or immunization, naïve T cells undergo a massive expansion culminating in the generation of a robust effector $T$ cell population. This peak effector response is relatively short-lived and, while most effector T cells die by apoptosis, some remain and develop into memory cells. Although the molecular mechanisms underlying this cell fate decision remain incompletely defined, substantial progress has been made, particularly with regards to $\mathrm{CD} 8^{+} \mathrm{T}$ cells. For example, the effector $\mathrm{CD}^{+}$ $T$ cells generated during a response are heterogeneous, consisting of cells with more or less potential to develop into full-fledged memory cells. Development of $\mathrm{CD}^{+}{ }^{+} \mathrm{T}$ cell memory is regulated by the transcriptional programs that control the differentiation and survival of effectorT cells. While the type of antigenic stimulation and level of inflammation control effector $\mathrm{CD}^{+} \mathrm{T}$ cell differentiation, availability of cytokines and their ability to control expression and function of $\mathrm{Bcl}-2$ family members governs their survival. These distinct differentiation and survival programs may allow for finer therapeutic intervention to control both the quality and quantity of $\mathrm{CD}^{+} \mathrm{T}$ cell memory. Effector to memory transition of $\mathrm{CD}^{+} \mathrm{T}$ cells is less well characterized than $\mathrm{CD}^{+} \mathrm{T}$ cells, emerging details will be discussed. This review will focus on the recent progress made in our understanding of the mechanisms underlying the development of $\mathrm{T}$ cell memory with an emphasis on factors controlling survival of effector T cells.

Keywords: CD8 ${ }^{+} \mathrm{T}$ cells, memory cells, $\mathrm{KLRG}^{\mathrm{hi}}{ }^{\mathrm{CD}} 127^{\mathrm{lo}}, \mathrm{Bim}, \mathrm{Bcl-2}$

\section{IMMUNOLOGICAL MEMORY}

The concept of immunological memory has dated back to as early as the fifth century B.C. as the Athenian author Thucydides mentioned in his scripts that people who survived plague would not be attacked a second time (Thucydides and Marchant, 1899). In seventh century, people drank snake venoms to get toxoidlike immunity (Plotkin etal., 2008). In ancient China, people blew powdered scabs of smallpox pustules into their nose to be protected from smallpox, a process called variolation (Plotkin et al., 2008). The process of variolation transferred to westward to the Middle East along shipping routes when Lady Mary Wortley Montagu witnessed this process and popularized variolation in England in the 1700s. By the time Edward Jenner immunized a child with cowpox and challenged him with smallpox, the concept of immune "memory" or "immunity" existed. Nearly 100 years elapsed before purposeful development of vaccines was attempted against cholera toxin and the rabies virus by Pasteur (Plotkin et al., 2008). Thus, the concept that prior exposure to a disease-causing microorganism (or a close relative) could provide long-lasted protection against subsequent infection has been around for a very long time. The subsequent large-scale development of effective vaccines against yellow fever, smallpox, rabies, influenza, polio, measles, mumps, diphtheria, Bordetella, hepatitis B, and, more recently, rotavirus have saved countless lives and are one of the greatest improvements to human health. Over the last few decades with the advent of cellular and molecular approaches we are started to unravel the mechanisms underlying immunological memory.

Immunological memory has been defined simply as the heightened immune response against a previously encountered pathogen that is due to the increased numbers of antigen-specific cells and their increased capacity to respond to secondary stimulation (Murphy et al., 2011). Both arms of adaptive immunity; antibody responses and $\mathrm{T}$ cell responses are quantitatively and qualitatively better than the primary responses. Immunological memory has been utilized successfully for generating protective immunity against many pathogens (Rappuoli, 2007). While it is clear that B cell production of antibody is critical for the protective features of many vaccines; long-lived T cell immunity is also critical component induced by vaccines. This review will focus on recent advances made in our understanding of mechanisms underlying the development of memory $\mathrm{T}$ cell responses. 


\section{TRACKING T CELL RESPONSES}

One of the substantial developments in T cell biology over the past few decades has been the ability to monitor $T$ cells responses at the single-cell level. Early work examining $\mathrm{T}$ cell function was restricted to population based assays such as proliferation $\left({ }^{3} \mathrm{H}\right.$ incorporation) for $\mathrm{CD} 4{ }^{+} \mathrm{T}$ cells and CTL assays $\left({ }^{51} \mathrm{Cr}\right.$ release) for $\mathrm{CD}^{+} \mathrm{T}$ cells. The development of TCR Tg mice and adoptive transfer approaches for the first time allowed tracking antigenspecific (albeit monoclonal) $\mathrm{T}$ cell responses to nominal antigens like ovalbumin (Kearney et al., 1994), to autoantigens (Katz et al., 1993), or to viral antigens (Pircher et al., 1990). It was not until the development of intracellular cytokine analysis by flow cytometry, that endogenous, polyclonal, antigen-specific T cell responses could be tracked at the single-cell level (Jung et al., 1993). While this was a critical development, it also required a brief stimulation of T cells either in vitro (Jung et al., 1993) or in vivo (Liu and Whitton, 2005), which could change the gene expression and phenotype of the cells. In addition, it only allowed for examination of cells whose cytokines are being measured, not necessarily all of the $\mathrm{T}$ cells responding to the antigen/infection. In contrast, the development of MHC tetramers was an absolutely critical tool for the tracking and analysis of endogenous $\mathrm{T}$ cell responses without the need for secondary stimulation (Altman et al., 1996). The development of these tools for tracking endogenous $\mathrm{T}$ cell responses has taught us a lot about $\mathrm{T}$ cell expansion, differentiation, and localization.

\section{KINETICS OF T CELL RESPONSES}

The initial reports tracking endogenous $\mathrm{T}$ cell responses characterized a massive expansion phase, in which responding $\mathrm{T}$ cells undergo 15-20 rounds of division, a "contraction" phase in which $80-90 \%$ of the responding T cells undergo apoptosis, and a "maintenance" phase in which the remaining effector cells persist as memory $\mathrm{T}$ cells and are maintained for the life of the animal (Butz and Bevan, 1998; Murali-Krishna et al., 1998; Williams and Bevan, 2007). For acute infections, the decline of T cell responses occurs just after the infection is cleared (Figure 1). Further, the expansion and contraction of $\mathrm{CD} 8^{+} \mathrm{T}$ cell responses are of a significantly greater magnitude compared with $\mathrm{CD} 4^{+} \mathrm{T}$ cell responses (Figure 1). While $\mathrm{CD}^{+} \mathrm{T}$ cell memory appears relatively stable over time, the $\mathrm{CD}^{+}$memory $\mathrm{T}$ cell population undergoes a gradual attrition (Figure 1). Nonetheless, a central question regarding the development of $\mathrm{T}$ cell memory is how some $\mathrm{T}$ cells avoid death and develop into memory $\mathrm{T}$ cells. Over the last decade, significant progress has been made regarding our understanding of the molecular mechanisms that contribute to the death of most effector $\mathrm{T}$ cells and to the transcriptional network that controls development of cells that are destined to become memory $\mathrm{T}$ cells. Herein, we will describe the current understanding of how $\mathrm{T}$ cells transit from potent effectors to lifelong protectors.

\section{HETEROGENEITY OF EFFECTOR T CELLS}

Effector $\mathrm{CD}^{+} \mathrm{T}$ cells are a heterogeneous population as defined by differential expression of surface markers. As only a small fraction of effector $\mathrm{T}$ cells develop into memory cells, there has been a quest to identify memory precursors early after infection.

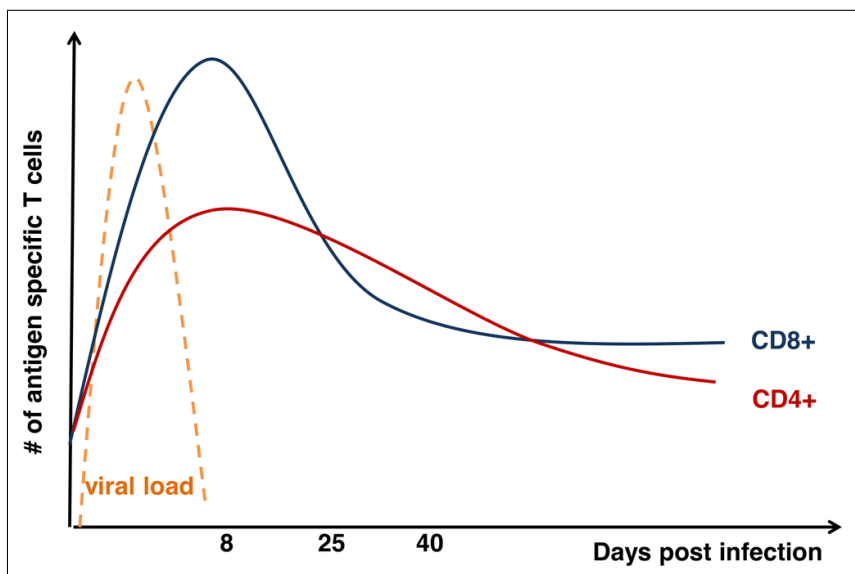

FIGURE 1 | Kinetics of T cell response after acute viral infection. Graph shows total numbers ( $y$-axis) of antigen-specific $\mathrm{CD}^{+}$(blue) and $\mathrm{CD}^{+}$ (red) $T$ cells days ( $x$-axis) after acute infection as modified from Hinds et al. (2007). Kinetics of viral load (orange) is also displayed on the graph.

Initially, it was unclear if memory cells went through an effector stage or whether they were a distinct lineage without effector characteristics. By using IFN- $\gamma$ reporter mice or granzyme B promoters, it has been shown that memory $\mathrm{CD}^{+} \mathrm{T}$ cells were derived from IFN- $\gamma$ producing and granzyme expressing effector cells, respectively (Harrington et al., 2008; Bannard et al., 2009). Importantly, adoptive transfer of a single naïve TCR transgenic $\mathrm{T}$ cell into congenic mice generated heterogeneous subsets of effector and memory CD8 ${ }^{+} \mathrm{T}$ cells in response to L. monocytogenes (Stemberger et al., 2007). Although these studies showed that memory cells are derived from effector cells, not every effector cell maintains the same potential to become memory cell over the course of infection. Many markers including cytokine receptors, chemokine receptors, and stimulatory/inhibitory receptors (described in more detail below) have been found to be differentially expressed among effector cells at the peak of the response (days 8-10 after infection). Among these markers, IL$7 \mathrm{R} \alpha$ (CD127) which is down-regulated on most of the effector cells early after infection (Schluns et al., 2000), but the proportion of cells expressing CD127 increases as the response contracts (Kaech et al., 2003).

Further characterization of these effector $\mathrm{CD}^{+} \mathrm{T}$ cells has revealed inverse expression of another marker, killer cell lectin-like receptor subfamily $\mathrm{G}$, member 1 (KLRG1) relative to expression of CD127 (Joshi etal., 2007). At the peak of the response, two major $\mathrm{CD}^{+}$effector $\mathrm{T}$ cell populations emerge, one being KLRG $1^{\text {hi }} \mathrm{CD} 127^{\text {lo }}$ and another being KLRG $1{ }^{\text {lo }} \mathrm{CD} 127^{\text {hi }}$ (Joshi et al., 2007). Although the two subsets had similar cytotoxicity and IFN- $\gamma$ production, KLRG $1^{\text {lo }} \mathrm{CD} 127^{\text {hi }}$ cells had better production of IL-2 (Sarkar et al., 2008). Adoptive transfer experiments using TCR Tg cells have revealed that KLRG1 ${ }^{\text {hi }} \mathrm{CD} 127^{\text {lo }}$ cells slowly declined over time after transfer while $\mathrm{KLRG} 1{ }^{\mathrm{lo}} \mathrm{CD} 127^{\text {hi }}$ cells were maintained at a greater level and persisted as long-lived memory T cells (Joshi et al., 2007; Sarkar et al., 2008). Because of these results, KLRG1 ${ }^{\text {hi }} \mathrm{CD} 127^{\text {lo }}$ have been referred to as "shortlived effector cells or SLECs" and KLRG $1^{\text {lo }} \mathrm{CD} 127^{\text {hi }}$ have been 
referred to as "memory precursor effector cells or MPECs" (Joshi et al., 2007). While these markers have been helpful in identifying certain populations of cells that have enrichments of cells with more or less potential to develop into memory, further work is necessary to more precisely define cells with memory potential. For example, while many SLECs die during contraction of the response, not all do, and after contraction of the response is largely complete, roughly half of the $\mathrm{CD} 8^{+} \mathrm{T}$ cells have an SLEC phenotype (Joshi et al., 2007; Kaech and Wherry, 2007). Likewise, when assessing the numbers temporally, roughly $30-40 \%$ of MPECs die during contraction of the response (Sarkar et al., 2008; Kurtulus et al., 2011).

Other markers in addition to KLRG1 and CD127 are also used to determine the memory potential of effector T cells. For instance, $\mathrm{CD} 127^{\text {hi }}$ cells also express high levels of CD27, which is a member of tumor necrosis factor receptor (TNF-R) family and the chemokine receptor, CXCR3, but these cells are found to have low expression of CD43 after infection with the Sendai virus (Kaech et al., 2003; Hikono et al., 2007). Thus, while these markers have helped identify cells with more or less ability to form long-lived memory cells, further work is necessary to more precisely define the cells within these subsets.

As primary infections have been difficult to assess in humans, it is unclear whether or not these precise effector subsets exist amongst human $\mathrm{T}$ cells. However, recent studies have shed light on effector cells in humans after vaccination with yellow fever virus and the smallpox vaccine (Miller et al., 2008; Akondy et al., 2009). Using MHC-peptide tetramers, the authors characterized the antigen-specific $\mathrm{T}$ cell response across the effector response and into memory from the peripheral blood. The phenotype of activated $\mathrm{CD} 8^{+} \mathrm{T}$ cells were characterized by high expression of HLA-DR and CD38 along with high expression of the proliferation marker Ki-67 and low expression of anti-apoptotic protein Bcl-2 and CD127 (Miller et al., 2008). As antigen-specific human $\mathrm{T}$ cells progressed into memory, they upregulated expression of CD127, CCR7, CD45RA, CD28, and Bcl-2 (Miller et al., 2008; Akondy et al., 2009). These memory cells were poly-functional and maintained after 2 years (Akondy etal., 2009). Although KLRG1 expression was not assessed in these studies, they showed that CD127 expression was similar in human and mouse $\mathrm{T}$ cells after infection. Thus, these studies showed that human and mouse effector $\mathrm{CD} 8^{+} \mathrm{T}$ cells share similar expression of several markers.

A more recent study performed a comprehensive analysis of 17 cell surface markers and 9 functional qualities of human $\mathrm{CD} 8^{+} \mathrm{T}$ cell subsets using single-cell spectrometric analysis (cytometry by time-of-flight or CyTOF; Newell et al., 2012). Functional qualities including expression of six different cytokines and cytotoxic granule components granzyme $B$ and perforin were examined together with surface markers including CD62L, CD45RA, CD45RO, CD27, CD43, and KLRG1. This study found that naïve cells (CD45RA ${ }^{+}$ $\left.\mathrm{CD}_{27}{ }^{+} \mathrm{CD}_{22} \mathrm{~L}^{+} \mathrm{CCR}^{+}\right)$, central memory $\mathrm{CD} 8^{+} \mathrm{T}$ cells $\left(\mathrm{T}_{\mathrm{CM}}\right.$; $\mathrm{CD} 4 \mathrm{RA}^{-} \mathrm{CD} 27^{+} \mathrm{CD} 2 \mathrm{~L}^{+} \mathrm{CCR}^{+}$), effector memory CD8 ${ }^{+} \mathrm{T}$ cells ( $\mathrm{T}_{\mathrm{EM}}$; $\mathrm{CD} 45 \mathrm{RA}^{-} \mathrm{CD}^{-} 7^{-} \mathrm{CD}^{-} \mathrm{L}^{-} \mathrm{CCR}^{-}$) cells and terminal effector cells $\left(\mathrm{CD} 45 \mathrm{RA}^{+} \mathrm{CD} 27^{-} \mathrm{CD}^{-} 2 \mathrm{~L}^{-} \mathrm{CD} 28^{-} \mathrm{KLRG}^{+}\right.$ $\mathrm{CD} 57^{+}$) represented quite distinct subsets as previously described (Sallusto et al., 1999). However, this study also found a range of cells with combinatorial diversity of phenotypic and functional markers in between these subsets suggesting a continuum of $\mathrm{T}$ cell phenotypes (Newell et al., 2012). Unfortunately, this did not longitudinally assess the response to infection as samples were obtained from chronically infected individuals. Thus, more work is needed to temporally examine the effector $\mathrm{T}$ cell subsets in humans during both acute and chronic infections in greater detail.

\section{GENERATION OF EFFECTOR CD8 ${ }^{+}$T CELL SUBSETS}

Recent work from a few labs has examined the potential in vivo plasticity of these subsets and has tracked their emergence from their naïve precursors. Interestingly, at the earliest times after the response when the cells can be reliably detected, a population appears that is KLRG $1{ }^{10} \mathrm{CD} 127^{\mathrm{lo}}$, which have been termed "early effector cells or EECs" (Obar et al., 2010). When EECs were adoptively transferred into timed-infected recipient mice, they were able to generate both $\mathrm{KLRG}{ }^{1 \mathrm{lo}} \mathrm{CD} 127^{\text {hi }}$ and $\mathrm{KLRG} 1^{\text {hi }} \mathrm{CD} 127^{\mathrm{lo}}$ cells; transferred KLRG $1{ }^{\text {lo }} \mathrm{CD} 127^{\text {hi }}$ cells were able to give rise to some EECs early after transfer but predominantly remained as KLRG $1{ }^{\text {lo }} \mathrm{CD} 127^{\text {hi }}$; while transferred KLRG $1{ }^{\text {hi }} \mathrm{CD} 127^{\text {lo }}$ cells were largely unable to generate $\mathrm{KLRG} 1^{\mathrm{lo}} \mathrm{CD} 127^{\mathrm{hi}}$ cells (Obar et al., 2011). Thus, shortly after the response, naïve T cells lose expression of CD127, some cells stably reacquire CD127 expression, while others upregulate KLRG1 and largely fail to upregulate CD127 (Joshi et al., 2007; Sarkar et al., 2008). At a molecular level this regulation of CD127 appears to be due to the competing effects of Gfi- 1 and GABP- $\alpha$ at the CD127 locus (Chandele et al., 2008). However, the mechanism(s) that control expression of Gfi-1 and GABP- $\alpha$ remain unclear.

As differential expression of KLRG1 and CD127 has allowed some demarcation of cells with more or less memory potential, much work has been focused on mechanisms underlying their generation. For example, one critical question is whether CD127 or KLRG1 are involved in the fate of effector T cells or whether they are simply markers. One initial idea was that expression of $\mathrm{CD} 127$ allowed effector $\mathrm{CD} 8^{+} \mathrm{T}$ cells to compete for IL-7 and, in doing so, was instructive for their survival and/or development into memory cells. However, while exogenous IL-7 could protect effector $\mathrm{CD} 4^{+}$and $\mathrm{CD} 8^{+} \mathrm{T}$ cells from contraction of the response (Tripathi et al., 2007; Nanjappa et al., 2008), transgenic expression of CD127 failed to prevent contraction of the response (Hand et al., 2007; Haring et al., 2008). Similarly, neutralization or inhibition of IL-7 after infection failed to substantially exacerbate contraction of the effector $\mathrm{CD} 4^{+}$or $\mathrm{CD}_{8}^{+} \mathrm{T}$ cell responses (Klonowski et al., 2006; Tripathi et al., 2007, 2010). A recent study has shown that KLRG1-deficient mice have no defects in memory T cell development (Grundemann et al., 2010), demonstrating that KLRG1 is not necessary for effector/memory $\mathrm{T}$ cell differentiation. However, given that there are multiple KLRG family members and the fact that KLRG1 possesses an immunoreceptor tyrosine-based inhibition motif (ITIM)-domain, makes it possible that KLRG1 contributes redundantly with other KLRG family members to limit signaling events within KLRG1 ${ }^{\text {hi }} \mathrm{CD} 127^{\mathrm{lo}}$ cells. On the other hand, if neither KLRG1 nor CD127 are instructive, what are the mechanisms that control generation of these two subsets? 


\section{INFLAMMATION DIRECTS EXPANSION OF KLRG1 ${ }^{\text {hi }}$ CD127 ${ }^{\text {lo }}$ CELLS}

Recent work has revealed an intriguing and complex interrelationship between transcriptional programs that balance input from surrounding inflammatory stimuli to promote a self-renewal program that maintains lifelong immunity. The transcription factor t-bet, initially described as a master regulator of Th1 fate, favors the generation of KLRG $1^{\text {hi }} \mathrm{CD} 127^{\text {lo }} \mathrm{CD} 8^{+} \mathrm{T}$ cells (Joshi et al., 2007). Loss of tbx21 (gene encoding t-bet) reduced the formation of KLRG $1{ }^{\text {hi }} \mathrm{CD} 127^{\text {lo }}$ effector $\mathrm{CD} 8^{+} \mathrm{T}$ cells, while graded increases in t-bet expression, whether retrovirally overexpressed or induced by varying amounts of inflammatory stimuli (e.g., TLR stimuli, IL12 , etc.) gradually increased the generation of KLRG ${ }^{\text {hi }} \mathrm{CD} 127^{\mathrm{lo}}$ $\mathrm{CD}^{+} \mathrm{T}$ cells (Badovinac and Harty, 2007; Joshi et al., 2007). Importantly, the overall numbers of $\mathrm{KLRG}^{\mathrm{lo}} \mathrm{CD} 127^{\mathrm{hi}} \mathrm{CD} 8^{+} \mathrm{T}$ cells in these t-bet titration experiments did not change, suggesting a critical role of t-bet in the formation of cells with a KLRG $1^{\text {hi }} \mathrm{CD} 127^{\text {lo }}$ phenotype, but not an MPEC phenotype.

Importantly, KLRG $1^{\text {hi }} \mathrm{CD} 127^{\text {lo }}$ cells express more t-bet compared to KLRG1 $1^{\text {lo }} \mathrm{CD} 127^{\text {hi }}$ cells, and the reverse is true for eomesodermin (eomes; Joshi et al., 2007, 2011). While neither subset is truly negative for either molecule, both are required for expression of CD122 and a lower t-bet:eomes ratio correlates with
KLRG $1{ }^{\text {lo }} \mathrm{CD} 127^{\text {hi }}$ cells and long-lived memory (Intlekofer et al., 2005, 2007; Banerjee et al., 2010). Thus, control of the t-bet:eomes ratio, as dictated by the level of inflammation is likely critical in controlling $\mathrm{CD}^{+} \mathrm{T}$ cell memory generation.

Understanding the regulation of this t-bet:eomes balance is the focus of several recent papers, which have outlined a complex interplay between t-bet and the mTORC1/AKT/FOXO signaling network (Figure 2). Overexpression of a constitutively active (ca) AKT transgene led to significantly increased expression of t-bet and a concomitant decrease in eomes expression (Kim et al., 2012). Conversely, caFOXO overexpression decreases expression of $\mathrm{t}$-bet and increases expression of eomes (Rao et al., 2012). Inflammation, via IL-12 (and possibly other inflammatory mediators) has been shown to increase mTORC1/AKT, which in turn decrease FOXO activity and enhance t-bet expression (Rao et al., 2010, 2012). However, a complicating factor in many of these studies is that caAKT appears to also decrease expression of CD127 (Hand et al., 2010), likely through inactivation of FOXO1 (Kerdiles et al., 2009), making it difficult to clearly distinguish the effector $\mathrm{CD}^{+}$subsets. Thus, while the current data suggest that mTORC1/AKT/FOXO signaling is differentially balanced between the subsets, it is also formally possible that a proper balance of mTORC1/AKT/FOXO signaling is necessary to emerge from the

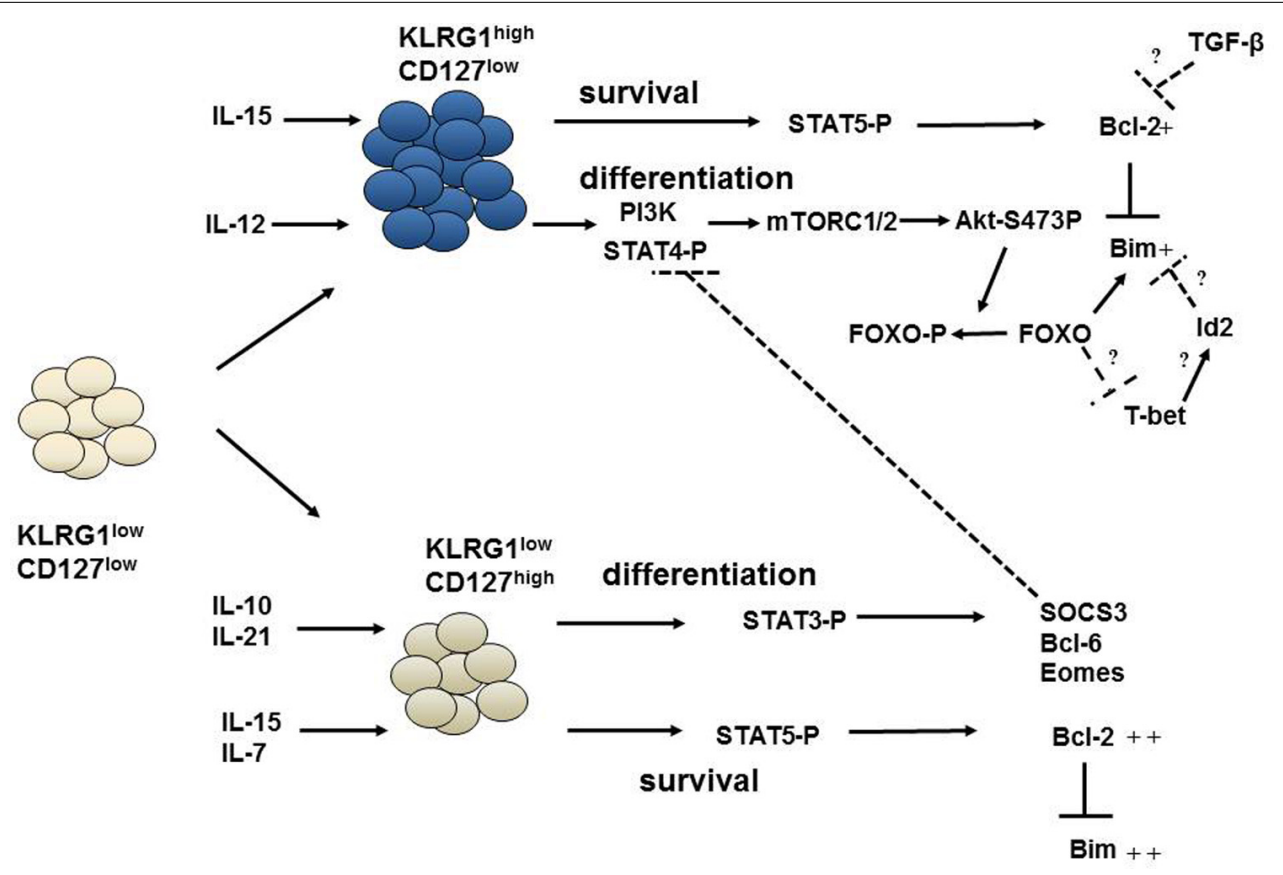

FIGURE 2 | Pathways governing the survival and differentiation of effector $\mathrm{CD8}^{+} \mathbf{T}$ cells. The differentiation of early effector cells $\left(\mathrm{KLRG} 1^{\text {lo }} \mathrm{CD} 127^{\mathrm{lo}}\right.$ ) into $\mathrm{KRLG} 1^{\text {hi }} \mathrm{CD} 127^{\mathrm{lo}}$ or $\mathrm{KLRG} 1^{\text {lo }} \mathrm{CD} 127^{\text {hi }}$ cells is regulated by inflammatory cytokines and by IL-10 and IL-21. IL-12 can activate STAT4 and PI-3K signaling which modulates mTOR kinases and subsequent Akt phosphorylation at s473. Phosphorylated Akt can phosphorylate and inactivate FOXO proteins. This favors an increased t-bet:eomes ratio and differentiation into $\mathrm{KLRG}{ }^{\text {hi }} \mathrm{CD} 127^{\mathrm{lo}}$ cells. On the other hand, Stat3 phosphorylation by IL-10 and IL-21 increases eomes and other transcription factors required for differentiation of $\mathrm{KLRG} 1^{\mathrm{lo}} \mathrm{CD} 127^{\mathrm{hi}}$ cells. SOCS3 induced by Stat3 can, then, inhibit IL-12 signaling, effectively shielding KLRG $1^{\text {lo }}$
CD127hi cells from inflammation. Interestingly, survival of effector subsets are regulated by $\gamma c$ cytokines IL-15 and IL-7 via signals driven through STAT5 which appear largely independent of differentiation. While KLRG $1^{\text {hi }} \mathrm{CD} 127^{\mathrm{lo}}$ cells can only receive IL-15 signals; IL-15 and IL-7 can both activate Stat5 signaling in $\mathrm{KLRG} 1^{\mathrm{lo}} \mathrm{CD} 127^{\mathrm{hi}}$ cells. This results in Bcl-2 upregulation and inhibition of Bim-mediated apoptosis. IL-15 becomes limiting for KLRG1 ${ }^{\text {hi }}$ $\mathrm{CD} 127^{10}$ cells reducing their ability to sustain $\mathrm{Bcl}-2$ levels in the face of TGF- $\beta$ signaling. Id2 may also control Bim levels in KLRG1 ${ }^{\text {hi }} \mathrm{CD} 127^{\mathrm{lo}}$ cells. FOXO proteins may be at the intersection of survival and differentiation pathways as it can regulate both Bim expression and influence the t-bet:eomes ratio. 
EEC compartment. More work will be necessary to cleanly dissect the factors that control mTORC1/AKT/FOXO signaling between the effector subsets.

\section{THE ROLE OF ANTIGEN PRESENTATION IN THE GENERATION OF EFFECTOR AND MEMORY CD $8^{+}$T CELLS}

Obviously, antigen initially drives the metamorphoses of naïve to effector T cell. Previous studies showed that limiting antigen exposure to the first $24 \mathrm{~h}$ was sufficient to drive expansion and differentiation into full-fledged effector (van Stipdonk et al., 2001) and memory (Kaech and Ahmed, 2001) cells in vitro. However, stimulation longer than $40 \mathrm{~h}$ in the presence of IL-12 resulted in a substantial increase in $\mathrm{CD}^{+}$clonal expansion compared to shorter stimulation, indicating the role of inflammatory cytokines in the magnitude of the response (Curtsinger et al., 2003). These studies suggested at least two interactions of $\mathrm{T}$ cells with antigenpresenting cells (APCs) promoted optimal effector and memory responses. Interestingly, limiting antigen display during Listeria infection by antibiotic treatment $24 \mathrm{~h}$ after infection resulted in a decreased magnitude of the response but a similar contraction (Badovinac etal., 2002). Secondary challenge of the antibiotic treated mice revealed an enhanced secondary response, despite the decreased magnitude of the primary response (Badovinac et al., 2002). Subsequently, it was found that antibiotic treatment prior to infection in this same model resulted in significantly enhanced generation of cells with a memory phenotype (CD127hi, Badovinac et al., 2004). However, in this study, it was shown that antibiotic treatment significantly decreased inflammation, and it was this attribute, rather than effects on antigen display that likely contributed to the increased memory cells (Badovinac et al., 2004). Similarly, adoptive transfer of naïve TCR Tg cells into mice with an ongoing immune response (as inflammation is waning), results in accelerated development of memory cells (D'Souza and Hedrick, 2006; Sarkar et al., 2007). Furthermore, attempts to restrict antigen display by elimination of dendritic cells (DCs) using CD11c-DTR mice also resulted in a decreased magnitude of the $\mathrm{CD} 8^{+} \mathrm{T}$ cell response, but accelerated development of cells with memory characteristics (Prlic et al., 2006). However, as DCs are also the same cells that secrete pro-inflammatory mediators, the degree to which their role as antigen presenters versus producers of inflammation is difficult to separate. Thus, while it is likely that limiting antigen display may contribute to memory cell development, further work is necessary to cleanly separate inflammatory stimuli from antigen-presentation.

\section{MIGRATION AND LOCALIZATION OF EFFECTOR AND MEMORY CD8 ${ }^{+}$T CELL SUBSETS}

Being at the right place at the right time may also be important for memory cell development. Indeed, recent work has shown that, in the spleen $\mathrm{KLRG} 1{ }^{\mathrm{lo}} \mathrm{CD} 127^{\mathrm{hi}} \mathrm{CD} 8^{+} \mathrm{T}$ cells are mostly localized to the $\mathrm{T}$ cell zones in the white pulp, while KLRG1 ${ }^{\text {hi }} \mathrm{CD} 127^{\text {lo }}$ $\mathrm{CD}^{+} \mathrm{T}$ cells are localized to the red pulp (Jung et al., 2010). CXCR3 signals may also be critical in attracting KLRG $1{ }^{\text {hi }} \mathrm{CD} 127^{\text {lo }}$ cells to the marginal zone areas, where they may be exposed to more inflammatory stimuli (Kurachi et al., 2011). Also, T cells in CXCR3/CCR5-deficient mice had similar problems with localization, actually failed to undergo contraction in the spleen, and had an emergence of KLRG $1^{10} \mathrm{CD} 127^{\text {hi }}$ cells (Kohlmeier et al., 2011). In these studies, it was also clear that the absence of CXCR3/CCR5 restricted the accumulation of effector $\mathrm{T}$ cells to sites of infection/inflammation as plenty of cells were recruited to the lung, but not to areas of viral replication within the infected lung. While overall tissue localization may direct $\mathrm{CD} 8^{+} \mathrm{T}$ cells to general areas of inflammation, the finer tuning of their migration within these organs is likely mediated by signals through CXCR3/CCR5. Intriguingly, CXCR3 signals through AKT/FOXO transcription factors raising the intriguing possibility that, in addition to promoting appropriate localization, differentiation signals driven by these chemokine receptors may also contribute to effector $\mathrm{T}$ cell heterogeneity. Conversely, high expression of CCR7 on KLRG $1^{10} \mathrm{CD} 127^{\text {hi }}$ cells likely fosters their migration to/retention within the T cell zones where the ligands CCL19 and CCL21 are highly expressed (Jung et al., 2010). This differential expression of CCR7 may be part of the effector $\mathrm{T}$ cell transcriptional program as t-bet and B lymphocyte-induced maturation protein-1 (Blimp1) can suppress CCR7 expression. Further, in the lymph nodes, fibroblastic reticular cells in T cell zones produce CCL19 and IL-7 (Link et al., 2007), thereby linking localization to $\mathrm{T}$ cell zones by CCR7 to IL-7 signals supporting survival of effector cells. It will be of great interest to determine whether it is simply the localization driven by chemokines that is critical for effector $\mathrm{CD}^{+} \mathrm{T}$ cell differentiation, or whether signaling by these chemokine receptors also contributes to effector cell heterogeneity and memory development.

\section{TRANSCRIPTIONAL PROGRAMING OF KLRG 1 hi CD127lo EFFECTOR T CELLS}

In addition to t-bet, other transcription factors have been shown to contribute to the formation of KLRG $1^{\text {hi }} \mathrm{CD} 127^{\mathrm{lo}}$ cells including the inhibitor of differentiation 2 (Id2) and Blimp-1 (Kallies et al., 2009; Yang et al., 2011). Id family proteins act as transcriptional repressors and often combat e-box proteins (Murre, 2005). Of the four members of Id family, both Id2 and Id 3 are reciprocally expressed in effector $\mathrm{CD} 8^{+} \mathrm{T}$ cell subsets. Id2 is more expressed in KLRG ${ }^{\text {hi }} \mathrm{CD} 127^{\text {lo }}$ cells, while Id 3 is more expressed in KLRG $1{ }^{\mathrm{lo}} \mathrm{CD} 127^{\text {hi }}$ cells (Yang et al., 2011). Id2-deficient mice generated a substantially reduced effector $\mathrm{CD} 8^{+} \mathrm{T}$ cell response to L. monocytogenes (Cannarile et al., 2006). This was further characterized in a follow-up study, where Id2 was found to be required for formation of KLRG $1^{\text {hi }} \mathrm{CD} 127^{\text {lo }}$ cells; and Id 3 was required for formation of KLRG $1{ }^{\mathrm{lo}} \mathrm{CD} 127^{\text {hi }}$ effector $\mathrm{CD} 8^{+} \mathrm{T}$ cells (Yang et al., 2011). Further studies showed that $\mathrm{E}$ proteins, E2A and HEB were required for generation of memory precursor KLRG $1{ }^{\mathrm{lo}} \mathrm{CD} 127^{\mathrm{hi}}$ effector $\mathrm{CD}^{+}{ }^{+} \mathrm{T}$ cells (D'Cruz et al., 2012). The limitation of E2A/HEB activity by Id proteins appears to set the balance between these two important effector $\mathrm{T}$ cell subsets.

Blimp1 is a transcription repressor in the PRDI-BF1 and RIZ homology domain containing (PRDM) family and also appears to contribute to formation of KLRG $1{ }^{\text {hi }} \mathrm{CD} 127^{\text {lo }}$ cells (Kallies et al., 2009; Rutishauser et al., 2009). Similar to Id proteins and E-box proteins, Blimp1 and another transcription repressor in the BTB/PZ family, Bcl-6 act as antagonists of each other (Tunyaplin et al., 2004; Cimmino et al., 2008). Blimp1 expression is higher in KLRG1 ${ }^{\mathrm{hi}} \mathrm{CD} 127^{\mathrm{lo}}$ cells and the absence of Blimp-1 
impairs development of these cells (Rutishauser et al., 2009). Multiple mechanisms may contribute to Blimp-1's role in promoting KLRG $1{ }^{\text {hi }} \mathrm{CD} 127^{\text {lo }}$ cells, including antagonization of Bcl-6 (Martins et al., 2006; Kallies et al., 2009), repression of IL-2 production (Martins et al., 2008). A recent report suggests that Blimp-1 may repress expression of Id 3 in $\mathrm{KLRG} 1{ }^{\text {hi }} \mathrm{CD} 127^{\text {lo }}$ cells and that lack of this repression (i.e., in Blimp-1-deficient mice) allows for their persistence into the memory compartment and for expression of E2A-driven genes important for genomic stability (Ji et al., 2011). Thus, the current data suggest a model in which inflammation drives expression of t-bet and an AKT/mTOR/FOXO signaling network that may contribute directly (by inducing Id2/Id3) or potentially in parallel with a Bcl-6/Id2/Id3 repressive network.

\section{TRANSCRIPTIONAL PROGRAMING OF MEMORY PRECURSOR EFFECTOR T CELLS}

Memory precursor effector cells are the Yin to the SLEC Yang and as such are often intertwined, experimental interpretations notwithstanding. Nonetheless, several factors have been reported to control the development of this effector cell population, including Bcl-6, TCF-1, and Stat3 (Figure 2). Deficiency in Tcf-1, an effector of the Wnt signaling pathway, impairs proliferative responses against Listeria infection and generation of $\mathrm{KLRG}{ }^{\mathrm{lo}} \mathrm{CD} 127^{\text {hi }}$ effector $\mathrm{CD}^{+}$T cells after Listeria (Zhou et al., 2010) and lymphocytic choriomeningitis virus (LCMV) infections (Jeannet et al., 2010). Zhou et al. (2010) also showed that Tcf-1 is essential for optimal eomes and IL-2R $\beta$ expression and forced overexpression of eomes partially prevented the decline of effector cells, although it did not appear to affect their surface marker phenotype. However, a role for $\beta$-catenin/wnt signaling on memory generation is controversial as two recent studies found that loss of $\beta$-catenin did not impair generation of effector responses (Driessens et al., 2010; Prlic and Bevan, 2011). In these studies, T cell-specific loss of $\beta$ catenin did not impair effector or secondary responses (as assessed by the frequency of tetramer ${ }^{+} \mathrm{T}$ cells up to day 30 after infection); however, the expression of KLRG1/CD127 markers were not assessed in this study (Prlic and Bevan, 2011). Although it is possible that a $\beta$-catenin-independent function of Tcf- 1 could contribute to formation of $\mathrm{KLRG} 1{ }^{\mathrm{lo}} \mathrm{CD} 127^{\text {hi }}$ cells, at least one study suggests that the effects of Tcf-1 on memory T cell development require its ability to interact with $\beta$-catenin (Jeannet et al., 2010). Thus, more work is required to determine the role of the wnt $/ \beta$-catenin/Tcf- 1 pathway on $\mathrm{KLRG} 1{ }^{\mathrm{lo}} \mathrm{CD} 127^{\text {hi }}$ cell formation and memory development.

Another recent study implicated STAT3, downstream of IL10 and IL-21 signaling as a critical regulator of development of memory precursor cells (Cui et al., 2011). Interestingly, this study showed that T cell-specific loss of STAT3 or neutralization of IL10 in an IL-21-deficient background lead to decreased percentage and number of KLRG $1^{\text {lo }} \mathrm{CD} 127^{\text {hi }}$ cells but an increased number of KLRG $1{ }^{\text {hi }} \mathrm{CD} 127^{\text {lo }}$ cells (Cui et al., 2011). Thus, while the overall numbers of effector cells did not change, their phenotype did, an important distinction and potential separation of the effects of differentiation from effects on survival at a time when responses are crashing. In this study, Stat3-deficient effector T cells had normal expression of eomes, Blimp-1, and Bcl-6 at the peak of the response their levels decreased over time (Cui et al., 2011). However, it was not apparent if this was a selective decrease in $\mathrm{KLRG} 1{ }^{\mathrm{lo}} \mathrm{CD} 127^{\mathrm{hi}}$ cells or the decrease was reflective of a shift in the effector subpopulations (Cui et al., 2011). SOCS-3, a known STAT-3 target gene was increased in wild type (WT) $\mathrm{KLRG} 1^{\mathrm{lo}} \mathrm{CD} 127^{\text {hi }}$ cells at the peak of the response, and these levels were decreased in STAT-3deficient cells, but again, subset-specific expression was not clear. Nonetheless, SOCS-3 overexpression in effector T cells reduced their ability to activate STAT4, whilst SOCS-3 knockdown promoted emergence of KLRG ${ }^{\text {hi }} \mathrm{CD} 127^{\text {lo }}$ cells. However, it remains unclear as to how these target genes may be selectively activated in $\mathrm{KLRG} 1{ }^{\text {lo }} \mathrm{CD} 127^{\text {hi }}$ cells because stimulation of effector $\mathrm{CD}^{+}$ T cells with IL-10 and IL-21 lead to homogenous STAT3 activation (Cui et al., 2011). Together, the data suggest an intriguing model whereby KLRG $1^{\text {lo }} \mathrm{CD} 127^{\text {hi }}$ cells are shielded from the differentiating effects of inflammation by STAT3-driven induction of SOCS-3.

\section{PARALLELS BETWEEN EFFECTOR AND MEMORY SUBSETS}

First described in humans, $\mathrm{T}_{\mathrm{CM}}$ express lymph node homing receptors $\mathrm{CD} 62 \mathrm{~L}$ and CCR7 and are mostly found in the lymph nodes and spleen as opposed to the $\mathrm{T}_{\mathrm{EM}}$ that lack CD62L and CCR7 expression and instead express a variety of chemokine receptors and tissue-specific homing receptors (Sallusto et al., 1999; Masopust etal., 2001). These two subsets also differ in their functional properties. $\mathrm{T}_{\mathrm{CM}}$ cells are capable of IL-2 production, self-renewal and they are multi-potent cells that can rapidly proliferate upon activation and generate effector cells (Wherry et al., 2003). Numbers of $\mathrm{T}_{\mathrm{CM}}$ cells gradually increase over time and outnumber $\mathrm{T}_{\mathrm{EM}}$ cells. While some studies suggest that the $\mathrm{T}_{\mathrm{EM}}$ subset converts to $\mathrm{T}_{\mathrm{CM}}$ over time (Wherry et al., 2003), others suggest that these lineages branch out early during memory differentiation and they are not convertible (Marzo et al., 2005). Adoptively transferred $\mathrm{T}_{\mathrm{EM}}$ cells were able to convert to CD62L $\mathrm{L}^{\text {hi }}$, CCR $7^{\text {hi }}$ CD $27^{\text {hi }}$ cells that could produce IL-2 (Wherry et al., 2003). However, responses of non-physiologically high numbers of P14 TCR transgenic T cells were shown to be different qualitatively compared to endogenous effector cells (Marzo et al., 2005). Nevertheless, both endogenous $\mathrm{T}_{\mathrm{EM}}$ cells and transfers of low number of P14 cells were shown to convert to $\mathrm{T}_{\mathrm{CM}}$ subset upon transfer (Sarkar et al., 2007). Although the conversion contributes to the increase in $\mathrm{T}_{\mathrm{CM}}$ numbers, CD62 $\mathrm{L}^{\text {hi }}$ effector $\mathrm{T}$ cells can be detected early after the infection and they are enriched within the KLRG $1^{\text {lo }} \mathrm{CD} 127^{\text {hi }}$ subset in the lymph nodes (Obar et al., 2011). On the other hand, KLRG $1^{\text {hi }} \mathrm{CD} 127^{\text {lo }}$ cells are low for the expression of CD62L (Sarkar et al., 2008). Thus, in addition to conversion, higher proliferation and better survival of $\mathrm{T}_{\mathrm{CM}}$ cells also contributes to the outgrowth of $\mathrm{T}_{\mathrm{CM}}$ cells later, after the infection has cleared. Reacquisition of $\mathrm{T}_{\mathrm{CM}}$ phenotype can be much slower after prime-boost immunizations (Jabbari and Harty, 2006; Masopust et al., 2006). Also, a greater fraction of secondary memory cells are KLRG $1{ }^{\text {hi }} \mathrm{CD} 127^{\text {hi }} \mathrm{CXCR} 3^{\text {lo }} \mathrm{CD} 27^{\text {lo }}$ phenotype (Masopust et al., 2006; Joshi et al., 2011). Although the recall responses of the adoptively transferred secondary memory cells were found to be even more potent than the responses of primary memory cells (Jabbari and Harty, 2006; Masopust et al., 2006), third generation memory cells had lower recall 
responses upon adoptive transfers as a result of further differentiation into KLRG1 ${ }^{\text {hi }}$ phenotype (Masopust et al., 2006). However, if the prime-boost immunizations are done in the same host; increased numbers of pre-existing memory cells prevent further differentiation into KLRG $1{ }^{\text {hi }} \mathrm{CXCR} 3{ }^{\text {lo }} \mathrm{CD} 62 \mathrm{~L}^{\text {lo }} \mathrm{CD} 27^{\text {lo }}$ phenotype (Joshi etal., 2011). Thus, the numbers of memory cells generated and the context of secondary priming conditions may affect the phenotype of secondary memory cells and these differences could play a role in the efficacy of prime-boost immunizations.

There are different models to explain the differentiation of memory cells from effector cells:

The early fate determination model predicts that memory cell heterogeneity, CD62 $\mathrm{L}^{\text {hi }}-\mathrm{CD}_{2} \mathrm{~L}^{\text {lo }}$ or CD127 ${ }^{\text {hi }}-\mathrm{CD}_{12} 7^{\mathrm{lo}}$ are fixed (pre-determined) at early times after infection. Indeed, effector cells with CD62L expression (Obar and Lefrancois, 2010) or CD127 expression (Kaech et al., 2003) can be detected before the peak of immune response. Similarly, Chang et al. (2007) visualized the TCR transgenic cells after priming and just before the first division and found that certain cell surface molecules or TCR signaling components segregated asymmetrically during division. They showed that certain receptors segregated to the putative distal pole relative to the microtubule organizing center (MTOC) which is formed close to the immunological synapse. This resulted in asymmetric cell division and the daughter cell containing the distal pole as to the synapse had more characteristics of memory $\mathrm{T}$ cells such as CD62L. This study, although incomplete, provided a mechanism as to how heterogeneity can be generated from a single $\mathrm{CD}^{+} \mathrm{T}$ cell during the first division (Chang et al., 2007). However, CD62L $\mathrm{L}^{\text {lo }}$ effector cells can also convert to CD62L hi cells (Wherry et al., 2003; Sarkar et al., 2007) which suggest that there is some flexibility during memory differentiation.

The decreasing potential model suggests that every effector cell has the potential to develop into a memory cell, but exposure to inflammation and antigen for longer periods of time can further differentiate effector cells into terminal effector cells (KLRG ${ }^{\text {hi }} \mathrm{CD} 127^{\mathrm{lo}}$ ) and decrease their potential to become memory cells (Ahmed and Gray, 1996; Badovinac et al., 2005; D’Souza and Hedrick, 2006).

A modified model proposed by Kaech and Wherry (2007), fate commitment with progressive differentiation suggests that there are memory precursors within the $\mathrm{KLRG} 1^{\mathrm{lo}} \mathrm{CD} 127^{\text {hi }}$ generated early in the immune response, but these cells are not fully mature memory cells and they require further differentiation. Although these cells have the potential for memory differentiation, they can develop into terminal effector cells (KLRG $1{ }^{\text {hi }} \mathrm{CD} 127^{\mathrm{lo}}$ ) if they encounter inflammatory signals. Importantly, this model appears to be consistent for the host response to several diverse infections (D'Souza and Hedrick, 2006; Badovinac and Harty, 2007; Joshi et al., 2007). As mentioned previously, IL-10 and IL-21 act to "shield" KLRG $1{ }^{\text {lo }} \mathrm{CD} 127^{\text {hi }}$ cells from the effects of inflammation, by increasing expression of SOCS3, which limits STAT-driven signals from inflammatory receptors (Cui et al., 2011). Thus, while differential expression of KLRG1 and CD127 can crudely mark cells with more or less memory potential, they likely require additional maturation signals and shielding from pro-inflammatory cytokines as they develop into full-fledged memory T cells.

\section{ENDOGENOUS MEMORY CELLS - IRRELEVANT BYSTANDER OR ACTIVE PARTICIPANT?}

In addition to infection-induced memory cells, it is well known that mice harbor populations of pre-existing memory $\mathrm{T}$ cells that bear markers of memory (CD44, Ly6c, etc.). Notably, these cells arise in mice that have not been purposefully challenged with infection. Admittedly, some of these cells might be specific for infections existing in some mouse colonies, for environmental antigens, or for gut flora. However, endogenous memory cells exist in gnotobiotic mice and recent data suggest that a fair number of these cells arise during thymic development (Dobber et al., 1992; Weinreich et al., 2010). A complex cellular and cytokine network, involving NKT cells and IL-4 appears to contribute to the development of pre-existing memory $\mathrm{T}$ cells, at least in Balb/c mice (Weinreich et al., 2010). Interestingly, in the process of quantifying the pre-existing naïve $\mathrm{T}$ cell compartment in unchallenged animals using peptide-MHC tetramers, Kedl's group found a significant frequency of $\mathrm{T}$ cells isolated from unchallenged mice bore memory markers (Haluszczak et al., 2009). They showed that, after purification these endogenous memory cells responded more robustly to stimulation, raising the intriguing possibility that this heterogeneity in the naïve compartment might contribute to effector T cell heterogeneity. On the other hand, in other experiments, transfer of a single TCR Tg T cell shows that effector and memory populations can arise from a single cell, a demonstration that differentiation from a common precursor is sufficient for effector and memory development. Whether or not there is a significant contribution of endogenous memory T cells to effector heterogeneity or whether these pre-existing cells contribute to epitope dominance at the population level (or both) remains to be determined.

\section{APOPTOSIS AND THE DEVELOPMENT OF T CELL MEMORY}

The molecular mechanisms responsible for apoptotic cell death have been investigated intensely over the last few decades. Mammalian cells have two major pathways to execute apoptosis: the extrinsic pathway (activated by death receptors of the TNF-R superfamily); and the intrinsic pathway (mostly controlled by members of the Bcl-2 gene family; Strasser, 2005). A considerable amount of experimental effort has been put into understanding $\mathrm{T}$ cell apoptosis. Initially, based on the discovery that defects in Fas signaling led to the accumulation of T cells in autoimmune lymphoproliferative syndrome (ALPS) patients and lpr/gld mice, and the requirement for Fas in an in vitro model of activated $T$ cell death it was assumed that Fas signaling was required for the contraction of T cell responses (Watanabe-Fukunaga et al., 1992; Takahashi et al., 1994; Brunner et al., 1995; Dhein et al., 1995; Fisher et al., 1995; Rieux-Laucat et al., 1995). However, while in vitro experiments readily showed a role for Fas/FasL signaling in activated $\mathrm{T}$ cell death, several experiments showed that contraction of $\mathrm{T}$ cell responses occurred readily in vivo in the absence of Fas signaling (Desbarats et al., 1998; Hildeman et al., 2002; Pellegrini et al., 2003). Thus, although disruptions of either pathway can affect $\mathrm{T}$ cell homeostasis, recent research has suggested a critical role for Bcl-2 family members and the intrinsic pathway in controlling contraction of $\mathrm{T}$ cell responses (Hildeman et al., 2002; Pellegrini et al., 2003; Wojciechowski et al., 2006). 
The Bcl-2 family can be classified into three subfamilies that have either pro- or anti-apoptotic function. Group 1 consists of anti-apoptotic Bcl-2-like molecules that contain most or all of the four Bcl-2 homology (BH) domains. Group 2 consists of Bax-like molecules that are pro-apoptotic and contain $\mathrm{BH}$ domains 1-3. Group 3 consists of $\mathrm{BH} 3$-only molecules that are pro-apoptotic and whose only homology to Bcl-2 lies in a short 9-10 amino acid stretch termed the $\mathrm{BH} 3$ domain. Group 3 has the most members, which appear to be expressed in a relatively tissue-specific fashion (Youle and Strasser, 2008). BH3-only molecules appear to transmit apoptotic signals to group two Bax-like molecules. In the absence of the two predominant Bax-like molecules, Bax and Bak, BH3-only proteins fail to induce apoptosis (Zong et al., 2001). The mechanism(s) by which BH3-only molecules transmit signals to Bax-like molecules remains the subject of some controversy. One model proposes direct interactions between certain $\mathrm{BH} 3$ only molecules and Bax-like molecules (Letai et al., 2002; Kuwana et al., 2005; Kim et al., 2006), while another proposes that BH3only molecules sequester anti-apoptotic molecules from Bax-like molecules and there is no direct interaction between $\mathrm{BH} 3$-only and Bax-like molecules (Willis et al., 2007). Despite the controversy both of these models highlight the importance of physical interactions between Bcl-2 family members in cell death/survival decisions. Thus, a major control point for cell death lies in the regulation of the balance between the levels of pro- and anti-apoptotic molecules.

The first experiment implicating Bcl-2 family members in activated $\mathrm{T}$ cell death showed that overexpression of Bcl-2 was sufficient to prevent $\mathrm{T}$ cell deletion in response to staphylococcal enterotoxin B (SEB; Strasser et al., 1991). We repeated this experiment and found that, in contrast to loss of Fas and TNF-R signaling, Bcl-2 overexpression gave a substantial protection from SEB-induced deletion (Hildeman et al., 2002). Likewise, loss of Bim provided a similar protection from deletion (Hildeman et al., 2002). Although previous reports showed that transgenic Bcl-2 overexpression failed to prevent contraction of viral-specific $\mathrm{T}$ cell responses, the level of the transgene across the response was never examined (Petschner et al., 1998). Notably, by mechanisms that remain unclear, the expression of endogenous $\mathrm{Bcl}-2$ in the human Bcl-2 transgenic mice that were used is substantially decreased, if not all together absent (Jorgensen et al., 2007). Further, following $\mathrm{T}$ cell activation, the levels of the Bcl-2 transgene also decline, making it less potent. Subsequently, our and other groups have observed that the loss of the Bcl-2 antagonist, Bim, prevents contraction of antigen-specific $\mathrm{CD}^{+}{ }^{+}$and $\mathrm{CD}^{+} \mathrm{T}$ cell responses to viral, bacterial, and parasitic infection (Pellegrini et al., 2003; Wojciechowski et al., 2006; Prlic and Bevan, 2008; Reckling et al., 2008). A major question is how T cells normally avoid Bim-driven death on their way to becoming memory $\mathrm{T}$ cells.

\section{REGULATION OF BCI-2 BY $\gamma$ C CYTOKINES}

Recent work from our and others groups have begun to address that question. In T cells, major controllers of Bcl-2 expression are the common gamma chain cytokines (Nakajima et al., 1997; Schluns et al., 2000; Berard et al., 2003; Wojciechowski et al., 2007). It has been known for some time that addition of IL-2, IL-4, IL-7, and IL-15 to activated or resting T cells promotes the expression of Bcl-2 (Vella et al., 1997, 1998) and Bcl-2 is largely required for in vitro $\mathrm{T}$ cell survival in response to these cytokines (Wojciechowski et al., 2007). The decreased expression of CD127 on the surface of $\mathrm{KLRG} 1^{\text {hi }} \mathrm{CD} 127^{\text {lo }} \mathrm{CD} 8^{+} \mathrm{T}$ cells renders them less sensitive to IL-7 and largely dependent upon IL-15 (Joshi et al., 2007; Rubinstein et al., 2008; Tripathi et al., 2010). CD127 ${ }^{\text {hi }}$ effector cells, on the other hand, require IL-7 and IL-15 for their optimal survival, although neutralization of IL-7 in an IL-15-deficient background only led to the loss of roughly half of this population (Tripathi et al., 2010). Thus, other $\gamma c$ cytokines probably also play a role in effector T cell survival because the loss of STAT5 signaling during the response led to a dramatic loss of both effector $\mathrm{CD} 8^{+} \mathrm{T}$ cell subsets (Tripathi et al., 2010). Mechanistically, STAT5 is critical for the ability of IL-7 and IL-15 to promote Bcl-2 expression (Tripathi et al., 2010). Thus, a common g cytokine/STAT5/Bcl-2 network is critical for maintaining effector $\mathrm{CD}^{+} \mathrm{T}$ cell responses (Figure 2).

While cytokine signaling through STAT5 promotes expression of $\mathrm{Bcl}-2$ it has been reported that TGF- $\beta$ signaling can antagonize Bcl-2 expression in KLRG1 ${ }^{\text {hi }} \mathrm{CD} 127^{\text {lo }}$ cells (Sanjabi et al., 2009). Adoptively transferred T cells expressing a dnTGF- $\beta$ R transgene had substantially increased expansion of effector cells, which was accompanied by increased expression of Bcl-2 (Sanjabi et al., 2009). Further, there appeared to be an intersection with IL-15 in this model, as transfer of dnTGF- $\beta \mathrm{R}$ Tg T cells into IL- 15 deficient mice led to a partial restoration of Bcl-2 levels compared to WT controls (Sanjabi et al., 2009). However, the increases in Bcl-2 were transient in dnTGF- $\beta \mathrm{R}$ Tg T cells and although there were increased $\mathrm{T}$ cells at the peak of the response, the contraction of the response was equal if not greater than the control, non-Tg animals (Sanjabi et al., 2009). Also, following $\mathrm{T}$ cell activation, levels of endogenous TGF- $\beta$ R decline dramatically making it unclear if this pathway is operative during the normal response or whether it is magnified by transgenic dnTGF- $\beta$ R overexpression.

\section{Bim/BcL-2 BALANCE IN EFFECTOR CD8+ T CELL SUBSETS}

Initial work describing $\mathrm{KLRG} 1^{\mathrm{lo}} \mathrm{CD} 127^{\text {hi }}$ and $\mathrm{KLRG} 1{ }^{\text {hi }} \mathrm{CD} 127^{\text {lo }}$ cells, showed that Bcl-2 expression was higher in $\mathrm{KLRG} 1^{\mathrm{lo}} \mathrm{CD} 127^{\text {hi }}$ cells and this was attributed to their prolonged survival (Joshi et al., 2007; Sarkar et al., 2008), however this was not formally tested. Using a combination and genetic and pharmacologic approaches, we tested the role of Bcl-2 in effector T cell survival, and its role in combating Bim within the effector subsets. Interestingly, we found that while Bcl-2 levels were higher in $\mathrm{KLRG} 1{ }^{\mathrm{lo}} \mathrm{CD} 127^{\text {hi }}$ cells than KLRG1 ${ }^{\text {hi }} \mathrm{CD} 127^{\text {lo }}$ cells, that Bim levels were also higher (Kurtulus et al., 2011). Genetic loss or inhibition of Bcl-2 led to a massive, Bim-dependent loss of KLRG $1^{\text {lo }} \mathrm{CD} 127^{\text {hi }}$ cells, and a less profound, but still significant loss of KLRG $1{ }^{\text {hi }} \mathrm{CD} 127^{\text {lo }}$ cells (Kurtulus et al., 2011). Notably, the cells that survived in the absence of Bcl-2 had significantly decreased levels of Bim (Kurtulus et al., 2011). This phenomenon may also explain the "Bcl-2 independence" of memory $\mathrm{T}$ cell survival reported in mice with a mutant IL-7R $\alpha$ transgene that is incapable of activating STAT5 and maintaining significant levels of Bcl-2 (Osborne et al., 2007). Thus, it is likely that Bcl-2 is an obligate defender of Bim to maintain survival of the memory precursor population, although the additional loss of Bim did not completely restore precursor cell numbers, suggesting that, in addition to restraining Bim, Bcl-2 may antagonize 
other pro-apoptotic molecules. Nonetheless, these data showed that Bcl-2 levels determined the levels of Bim that effector T cells can tolerate and survive (Figure 2).

While decreased expression of Bcl-2 certainly contributes to the demise of effector $\mathrm{CD}^{+} \mathrm{T}$ cells, changes in Bim expression are difficult to detect because once past a certain Bcl-2 level, cells having higher expression of Bim would be lost by apoptosis. We circumvented this issue by using mice that were deficient in Bak, but had a $\mathrm{T}$ cell-specific loss of Bax, making them insensitive to death driven by BH3-only Bcl-2 family members (Zong et al., 2001; Kurtulus et al., 2011). Loss of Bax and Bak led to accrual of T cells with significantly increased levels of Bim, suggesting that there is indeed a rather significant transcriptional induction of Bim during the response (Kurtulus et al., 2011). Importantly, the levels of Bcl-2 were also decreased significantly in these "undead" cells effectively uncoupling concordant Bim and Bcl-2 expression. Because of the inherent toxicities associated with altered expression of Bim, it has been difficult to determine the factors that control Bim expression in T cells. However, recent work has suggested that FOXO3a and Id 2 may be regulators of Bim within effector T cells, as loss of FOXO3a led to decreased Bim protein (Sullivan et al., 2012), while loss of Id2 led to increased Bim mRNA (Cannarile et al., 2006). It is possible that there are intersections between FOXO3a and Id2 proteins, as deficiencies in either molecule led to major effects on expansion but rather minor effects on contraction of the response (Figure 2). Thus, more work will be necessary to clearly examine the complex transcriptional network underlying effector $\mathrm{T}$ cell contraction.

\section{DEVELOPMENT OF CD4 MEMORY - CONSIDERABLY DIFFERENT FROM DEVELOPMENT OF CD8 MEMORY}

Although much more work has been done to define effector $\mathrm{T}$ cell subsets and control of $\mathrm{CD}^{+} \mathrm{T}$ cell memory, clues are emerging to define effector CD4 responses and the development of memory $\mathrm{CD}^{+} \mathrm{T}$ cells. Interestingly, it appears that the markers expressed on effector $\mathrm{CD} 8^{+} \mathrm{T}$ cells and those expressed on effector $\mathrm{CD}^{+}{ }^{+} \mathrm{T}$ cells are quite distinct. For example, expression of CD127 on effector CD4 ${ }^{+} \mathrm{T}$ cells is more dynamic; CD127 effector $\mathrm{CD}^{+}{ }^{+} \mathrm{T}$ cells readily re-express CD127. Several recent studies have examined heterogeneity within effector $\mathrm{CD} 4^{+} \mathrm{T}$ cells. One study found that subsets of effector $\mathrm{CD} 4^{+} \mathrm{T}$ cells could be defined based expression of P-selectin ligand-1 (PSGL-1) and Ly6C into three distinct, PSGL-1 ${ }^{\text {low }}$ Ly6C ${ }^{\text {low }}$, PSGL- ${ }^{\text {hi }}$ Ly6C ${ }^{\text {low }}$, and PSGL-1 ${ }^{\text {hi }}$ Ly6C ${ }^{\text {hi }}$ (Marshall et al., 2011). Over time after infection, there was a slight enrichment for PSGL- ${ }^{\text {hi }}$ Ly6C ${ }^{\text {low }}$ cells, but this enrichment was not nearly as dramatic as the enrichment for KLRG $1^{\text {lo }} \mathrm{CD} 127^{\text {hi }}$ cells within the effector CD8 compartment. However, similar to the KLRG $1^{\text {hi }} \mathrm{CD} 127^{\text {lo }} \mathrm{CD} 8^{+} \mathrm{T}$ cells PSGL$1^{\text {hi }}$ Ly6C $^{\text {hi }} \mathrm{CD}^{+}{ }^{+}$population required t-bet expression (Marshall et al., 2011). Thus, while effector PSGL- $1^{\text {hi }}$ Ly6C ${ }^{\text {low }}$ cells appeared to be more capable of expanding in response to a secondary challenge, and that they share a similar transcriptional profile with memory CD4 ${ }^{+} \mathrm{T}$ cells (Marshall et al., 2011), suggests that this subset most likely contains memory precursors.

On the other hand, another study defined effector $\mathrm{CD} 4^{+}$subsets via expression of CXCR5 and PD-1 (Pepper et al., 2011). Effector $\mathrm{CD} 4^{+} \mathrm{T}$ cells were again divided into three major subsets, cells expressing CCR7 along with intermediate levels of CXCR5 and lacking PD-1 (termed Tcm), those expressing t-bet, but not CCR7, CXCR5 nor PD-1 (Th1), and those expressing CXCR5 and PD-1 (Tfh). While Tfh cells waned dramatically over time, Th1 cells contracted more vigorously and Tcm cells contracted less vigorously (Pepper et al., 2011). In secondary responses, Tcm cells gave rise to all three subsets, while Th1 cells gave rise to only Th1 cells, suggesting that the Th1 cells, when they exist as memory cells are less able to give rise to the other subsets, while subset differentiation ability is maintained in the Tcm population. This study also showed that the Th1 cells largely required CD25 expression, while Bcl-6 was critical for Tcm cells as was inducible costimulator (ICOS) stimulation from B cells (Pepper et al., 2011). Importantly, while Tcm and Tfh both required Bcl-6, it is notable that they are discrete populations due to their differential localization after adoptive transfer and the fact that Tcm cells are inefficient at producing Tfh cells in secondary responses (Pepper et al., 2011). The overlap and relationship between the effector $\mathrm{CD} 4^{+} \mathrm{T}$ cell subsets identified by these two studies remains unclear and awaits further investigation.

The expansion and contraction of the $\mathrm{CD} 4^{+} \mathrm{T}$ cell response also shares both similarities and differences contraction of the $\mathrm{CD}^{+}$ $\mathrm{T}$ cell response. It has been known for some time that expansion of the CD4 response is less robust than the CD8 response (Homann et al., 2001). Further, the decline of the antigen-specific effector $\mathrm{CD}^{+}{ }^{+} \mathrm{T}$ cells after the peak of the response is less steep (90-95\% of effector CD8s are lost; compared to 75-80\% of effector $\mathrm{CD} 4 \mathrm{~s}$ ) within the 2-3 weeks after the peak of the response (Figure 1). After that early contraction, memory $\mathrm{CD} 8^{+} \mathrm{T}$ cells are maintained at a constant level while $\mathrm{CD} 4^{+} \mathrm{T}$ cells decline slowly over time (Homann etal., 2001; Pepper et al., 2011; Figure 1). However, the pro-apoptotic molecule Bim is critical to the demise of both populations; the absence of Bim spares roughly $80 \%$ of the effector $\mathrm{CD}^{+}{ }^{+} \mathrm{T}$ cells and $>90 \%$ of the effector $\mathrm{CD} 4^{+} \mathrm{T}$ cells (Wojciechowski et al., 2006). Interestingly, there are some basic differences in how effector $\mathrm{CD}^{+}{ }^{+}$versus $\mathrm{CD} 8^{+} \mathrm{T}$ cells combat Bim in order to enter the memory compartment. We and others recently showed that IL-7 and IL-15 contribute to survival of effector $\mathrm{CD}^{+}$T cells by promoting expression of Bcl-2 through STAT5 (Schluns et al., 2000, 2002; Rubinstein et al., 2008; Tripathi et al., 2010). However, we found that neutralization of IL-7 in IL-15deficient mice did not result in significantly increased contraction of the CD4 ${ }^{+} \mathrm{T}$ cell response (Tripathi et al., 2010). Further, we found that, in contrast to $\mathrm{CD} 8^{+} \mathrm{T}$ cells, effector $\mathrm{CD} 4^{+} \mathrm{T}$ cells were much more able to tolerate the loss of STAT5 and persisted for some time as STAT5 ${ }^{\text {low }}$ effector T cells (Tripathi et al., 2010). Similarly, neutralization of Bcl-2 does not exacerbate contraction of the $\mathrm{CD}^{+} \mathrm{T}$ cell response (Tripathi et al., 2007), suggesting that, in effector $\mathrm{CD}^{+}{ }^{+} \mathrm{T}$ cells, something other than Bcl-2 combats Bim. Thus, while there are some similarities with effector to memory transition between $\mathrm{CD} 4^{+}$and $\mathrm{CD}^{+}{ }^{+} \mathrm{T}$ cells more work is necessary to untangle the mechanisms that control this transition.

\section{FUTURE DIRECTIONS}

Recent progress has greatly improved our understanding of how memory $\mathrm{T}$ cells emerge from the effector pool. Death and differentiation work together to shape the effector T cell response. 
Most effector $\mathrm{T}$ cells that are generated die shortly after the peak of the response. This death process is largely mediated by the pro-apoptotic Bcl-2 family member, Bim. Bim function is negatively controlled by the levels of Bcl-2, which are regulated by the availability of common gamma chain cytokines. Death and differentiation could be manipulated to enhance the death of autoreactive $\mathrm{T}$ cells. On the other hand, manipulation of death and differentiation processes could be exploited to improve vaccine responses. For example, recent work from us and other have suggested that IL-7 may be an excellent vaccine adjuvant, promoting strong effector $\mathrm{T}$ cell responses to help $\mathrm{B}$ cells make antibody as well as promoting strong effector $\mathrm{CD} 4^{+}$and $\mathrm{CD} 8^{+}$ T cell responses (Tripathi et al., 2007; Nanjappa et al., 2008; Nam et al., 2010; Pellegrini et al., 2011). However, the effects of IL-7 are somewhat short-lived as they wane with the withdrawal of the cytokine. Thus, factors that restrict cellular differentiation (i.e., IL-10, IL-21) may be combined with IL-7 therapy to boost long-lived central memory $\mathrm{T}$ cells. This may be particularly advantageous for vaccines that require boosting to achieve immunity,

\section{REFERENCES}

Ahmed, R., and Gray, D. (1996). Immunological memory and protective immunity: understanding their relation. Science 272, 54-60.

Akondy, R. S., Monson, N. D., Miller, J. D., Edupuganti, S., Teuwen, D., Wu, H., et al. (2009). The yellow fever virus vaccine induces a broad and polyfunctional human memory $\mathrm{CD}^{+} \mathrm{T}$ cell response. J. Immunol. 183, 7919-7930.

Altman, J. D., Moss, P. A., Goulder, P. J., Barouch, D. H., Mcheyzer-Williams, M. G., Bell, J. I., et al. (1996). Phenotypic analysis of antigen-specific $\mathrm{T}$ lymphocytes. Science 274, 94-96.

Bachmann, M. F., Wolint, P., Schwarz, K., and Oxenius, A. (2005). Recall proliferation potential of memory $\mathrm{CD}^{+} \mathrm{T}$ cells and antiviral protection. J. Immunol. 175, 4677-4685.

Badovinac, V. P., and Harty, J. T. (2007). Manipulating the rate of memory $\mathrm{CD}^{+} \mathrm{T}$ cell generation after acute infection. J. Immunol. 179, 53-63.

Badovinac, V. P., Messingham, K. A., Jabbari, A., Haring, J. S., and Harty, J. T. (2005). Accelerated CD8 ${ }^{+}$T-cell memory and prime-boost response after dendritic-cell vaccination. Nat. Med. 11, 748-756.

Badovinac, V. P., Porter, B. B., and Harty, J. T. (2002). Programmed contraction of CD8 $(+)$ T cells after infection. Nat. Immunol. 3, 619-626.

Badovinac, V. P., Porter, B. B., and Harty, J. T. (2004). CD8 ${ }^{+}$T cell contraction is controlled by early inflammation. Nat. Immunol. 5, 809-817.

Banerjee, A., Gordon, S. M., Intlekofer, A. M., Paley, M. A., Mooney, E. C., Lindsten, T., et al. (2010). Cutting edge: the transcription factor eomesodermin enables CD ${ }^{+} \mathrm{T}$ cells to compete for the memory cell niche. J. Immunol. 185, 4988-4992.

Bannard, O., Kraman, M., and Fearon, D. T. (2009). Secondary replicative function of $\mathrm{CD}^{+} \mathrm{T}$ cells that had developed an effector phenotype. Science 323, 505-509.

Berard, M., Brandt, K., Bulfone-Paus, S., and Tough, D. F. (2003). IL-15 promotes the survival of naive and memory phenotype $\mathrm{CD} 8^{+} \mathrm{T}$ cells. $J$. Immunol. 170, 5018-5026.

Brunner, T., Mogil, R. J., Laface, D. Yoo, N. J., Mahboubi, A., Echeverri, F., et al. (1995). Cell-autonomous Fas (CD95)/Fas-ligand interaction mediates activation-induced apoptosis in T-cell hybridomas. Nature 373, 441-444.

Butz, E. A., and Bevan, M. J. (1998). Massive expansion of antigenspecific $\mathrm{CD}^{+} \mathrm{T}$ cells during an acute virus infection. Immunity 8 , 167-175.

Cannarile, M. A., Lind, N. A., Rivera, R., Sheridan, A. D., Camfield, K. A., $\mathrm{Wu}$, B. B., et al. (2006). Transcriptional regulator $\mathrm{Id} 2$ mediates $\mathrm{CD} 8^{+}$ T cell immunity. Nat. Immunol. 7, 1317-1325.

Chandele, A., Joshi, N. S., Zhu, J., Paul, W. E., Leonard, W. J., and Kaech, S. M. (2008). Formation of IL-7Ralphahigh and IL-7Ralphalow CD8 $\mathrm{T}$ cells during infection is regulated by the opposing functions of GABPalpha and Gfi-1. J. Immunol. 180, 5309-5319.

Chang, J. T., Palanivel, V. R., Kinjyo, I., Schambach, F., Intlekofer, A. M., Banerjee, A., et al. (2007). Asymmetric $\mathrm{T}$ lymphocyte division in the initiation of adaptive

such as the hepatitis B vaccine. Conversely, other vaccines may benefit from effector memory $\mathrm{T}$ cells, which are maintained in the tissues and provide substantial protection from tissue borne infections (Bachmann et al., 2005). For example, adenoviral vaccines appear to promote strong effector $\mathrm{T}$ cells that appear to persist as effector memory cells (Reyes-Sandoval et al., 2011). Thus, more research is necessary to define successful immunization strategies that maximize protective immunity. Exploitation of combinatorial strategies aimed at controlling the type of inflammation with enhancing effector $\mathrm{T}$ cell survival may provide approaches that could be tailored to the particular infectious disease.

\section{ACKNOWLEDGMENTS}

The authors wish to thank the members of the David A. Hildeman lab for helpful input and discussion. The authors apologize to the researchers whose work could not be comprehensively covered here. This work was supported by U.S. Public Health Service Grants AI057753, AG033057, and DK081175 (to David A. Hildeman).

immune responses. Science 315, 1687-1691.

Cimmino, L., Martins, G. A., Liao, J., Magnusdottir, E., Grunig, G., Perez, R. K., et al. (2008). Blimp-1 attenuates Th1 differentiation by repression of ifng, tbx21, and bcl6 gene expression. J. Immunol. 181, 23382347.

Cui, W., Liu, Y., Weinstein, J. S. Craft, J., and Kaech, S. M. (2011). An interleukin-21-interleukin10-STAT3 pathway is critical for functional maturation of memory $\mathrm{CD}^{+}$T cells. Immunity 35, 792-805.

Curtsinger, J. M., Johnson, C. M., and Mescher, M. F. (2003). CD8 T cell clonal expansion and development of effector function require prolonged exposure to antigen, costimulation, and signal 3 cytokine. J. Immunol. 171, 5165-5171.

D'Cruz, L. M., Lind, K. C., Wu, B. B., Fujimoto, J. K., and Goldrath, A W. (2012). Loss of E protein transcription factors E2A and HEB delays memory-precursor formation during the CD8(+) T-cell immune response. Eur. J. Immunol. 42, 2031-2041.

Desbarats, J., Duke, R. C., and Newell, M. K. (1998). Newly discovered role for Fas ligand in the cell-cycle arrest of arrest of $\mathrm{CD} 4^{+} \mathrm{T}$ cells. Nat. Med 4, 1377-1382.

Dhein, J., Walczak, H., Baumler, C., Debatin, K. M., and Krammer, P. H. (1995). Autocrine T-cell suicide mediated by APO1/(Fas/CD95). Nature 373, 438-441.

Dobber, R., Hertogh-Huijbregts, A., Rozing, J., Bottomly, K., and Nagelkerken, L. (1992). The involvement of the intestinal microflora in the expansion of $\mathrm{CD}^{+} \mathrm{T}$ cells with a naive phenotype in the periphery. Dev. Immunol. 2, 141-150.

Driessens, G., Zheng, Y., and Gajewski, T. F. (2010). Beta-catenin does not regulate memory $\mathrm{T}$ cell phenotype. Nat. Med. 16, 513-514; author reply 514-515.

D'Souza, W. N., and Hedrick, S. M. (2006). Cutting edge: latecomer CD8 $\mathrm{T}$ cells are imprinted with a unique differentiation program. J. Immunol. 177, 777-781.

Fisher, G. H., Rosenberg, F. J., Straus, S. E., Dale, J. K., Middleton, L. A., Lin, A. Y., et al. (1995). Dominant interfering Fas gene mutations impair apoptosis in a human autoimmune lymphoproliferative syndrome. Cell 81, 935-946.

Grundemann, C., Schwartzkopff, S., Koschella, M., Schweier, O., Peters, C., Voehringer, D., et al. (2010). The NK receptor KLRG1 is dispensable for virus-induced $\mathrm{NK}$ and $\mathrm{CD} 8{ }^{+} \mathrm{T}$ cell differentiation and function in vivo. Eur. J. Immunol. 40, 1303-1314.

Haluszczak, C., Akue, A. D., Hamilton, S. E., Johnson, L. D., Pujanauski, L., Teodorovic, L., et al. (2009). The antigen-specific $\mathrm{CD}^{+}{ }^{+} \mathrm{T}$ cell repertoire in unimmunized mice includes memory phenotype cells bearing markers of homeostatic expansion. J. Exp. Med. 206, 435-448.

Hand, T. W., Cui, W., Jung, Y. W., Sefik, E., Joshi, N. S., Chandele, A., et al. (2010). Differential effects of STAT5 and PI3K/AKT signaling on effector and memory CD8 T-cell survival. Proc. Natl. Acad. Sci. U.S.A. 107, 16601-16606.

Hand, T. W., Morre, M., and Kaech, S. M. (2007). Expression of IL-7 receptor alpha is necessary but not 
sufficient for the formation of memory CD8 T cells during viral infection. Proc. Natl. Acad. Sci. U.S.A. 104, 11730-11735.

Haring, J. S., Jing, X., BollenbacherReilley, J., Xue, H. H., Leonard, W. J., and Harty, J. T. (2008). Constitutive expression of IL-7 receptor alpha does not support increased expansion or prevent contraction of antigenspecific CD4 or CD8 T cells following Listeria monocytogenes infection. J. Immunol. 180, 2855-2862.

Harrington, L. E., Janowski, K. M., Oliver, J. R., Zajac, A. J., and Weaver, C. T. (2008). Memory CD4 T cells emerge from effector T-cell progenitors. Nature 452, 356-360.

Hikono, H., Kohlmeier, J. E., Takamura, S., Wittmer, S. T., Roberts, A. D., and Woodland, D. L. (2007) Activation phenotype, rather than central- or effector-memory phenotype, predicts the recall efficacy of memory CD8 ${ }^{+}$T cells. J. Exp. Med. 204, 1625-1636.

Hildeman, D. A., Zhu, Y., Mitchell, T. C., Bouillet, P., Strasser, A., Kappler, J., et al. (2002). Activated T cell death in vivo mediated by proapoptotic bcl2 family member bim. Immunity 16 , 759-767.

Hinds, M. G., Smits, C., FredericksShort, R., Risk, J. M., Bailey, M., Huang, D. C., et al. (2007). Bim, Bad and Bmf: intrinsically unstructured $\mathrm{BH} 3$-only proteins that undergo a localized conformational change upon binding to prosurvival Bcl-2 targets. Cell Death Differ. 14, 128-136.

Homann, D., Teyton, L., and Oldstone, M. B. (2001). Differential regulation of antiviral T-cell immunity results in stable $\mathrm{CD}^{+}$but declining $\mathrm{CD} 4^{+}$ T-cell memory. Nat. Med. 7, 913-919. Intlekofer, A. M., Takemoto, N., Kao, C., Banerjee, A., Schambach, F., Northrop, J. K., et al. (2007). Requirement for T-bet in the aberrant differentiation of unhelped memory CD8 ${ }^{+}$ T cells. J. Exp. Med. 204, 2015-2021.

Intlekofer, A. M., Takemoto, N., Wherry, E. J., Longworth, S. A., Northrup, J. T., Palanivel, V. R., et al. (2005). Effector and memory $\mathrm{CD}^{+} \mathrm{T}$ cell fate coupled by T-bet and eomesodermin. Nat. Immunol. 6, 1236-1244.

Jabbari, A., and Harty, J. T. (2006). Secondary memory $\mathrm{CD}^{+} \mathrm{T}$ cells are more protective but slower to acquire a central-memory phenotype. J. Exp. Med. 203, 919-932.

Jeannet, G., Boudousquie, C., Gardiol, N., Kang, J., Huelsken, J., and Held, W. (2010). Essential role of the Wnt pathway effector Tcf-1 for the establishment of functional CD8 $\mathrm{T}$ cell memory. Proc. Natl. Acad. Sci. U.S.A. 107, 9777-9782.

Ji, Y., Pos, Z., Rao, M., Klebanoff, C. A., Yu, Z., Sukumar, M., et al. (2011). Repression of the DNAbinding inhibitor Id 3 by Blimp-1 limits the formation of memory $\mathrm{CD}^{+}$ $\mathrm{T}$ cells. Nat. Immunol. 12, 1230 1237.

Jorgensen, T. N., Mckee, A., Wang, M., Kushnir, E., White, J., Refaeli, Y., et al. (2007). Bim and Bcl-2 mutually affect the expression of the other in T cells. J. Immunol. 179, 3417-3424.

Joshi, N. S., Cui, W., Chandele, A., Lee, H. K., Urso, D. R., Hagman, J., et al. (2007). Inflammation directs memory precursor and short-lived effector CD8(+) $\mathrm{T}$ cell fates via the graded expression of T-bet transcription factor. Immunity 27, 281-295.

Joshi, N. S., Cui, W., Dominguez, C. X., Chen, J. H., Hand, T. W., and Kaech, S. M. (2011). Increased numbers of preexisting memory CD8 T cells and decreased T-bet expression can restrain terminal differentiation of secondary effector and memory CD8 T cells. J. Immunol. 187, 40684076.

Jung, T., Schauer, U., Heusser, C., Neumann, C., and Rieger, C. (1993). Detection of intracellular cytokines by flow cytometry. J. Immunol. Methods 159, 197-207.

Jung, Y. W., Rutishauser, R. L., Joshi, N. S., Haberman, A. M., and Kaech, S. M. (2010). Differential localization of effector and memory CD8 T cell subsets in lymphoid organs during acute viral infection. J. Immunol. 185, 5315-5325.

Kaech, S. M., and Ahmed, R. (2001) Memory $\mathrm{CD}^{+} \mathrm{T}$ cell differentiation: initial antigen encounter triggers a developmental program in naive cells. Nat. Immunol. 2, 415-422.

Kaech, S. M., Tan, J. T., Wherry, E. J., Konieczny, B. T., Surh, C. D., and Ahmed, R. (2003). Selective expression of the interleukin 7 receptor identifies effector CD8 T cells that give rise to long-lived memory cells. Nat. Immunol. 4, 1191-1198.

Kaech, S. M., and Wherry, E. J. (2007). Heterogeneity and cell-fate decisions in effector and memory $\mathrm{CD}^{+} \mathrm{T}$ cell differentiation during viral infection. Immunity 27, 393-405.

Kallies, A., Xin, A., Belz, G. T., and Nutt, S. L. (2009). Blimp-1 transcription factor is required for the differentiation of effector CD8(+) $\mathrm{T}$ cells and memory responses. Immunity 31, 283-295.

Katz, J. D., Wang, B., Haskins, K., Benoist, C., and Mathis, D. (1993). Following a diabetogenic $\mathrm{T}$ cell from genesis through pathogenesis. Cell 74, 1089-1100.

Kearney, E. R., Pape, K. A., Loh, D. Y., and Jenkins, M. K. (1994). Visualization of peptide-specific $\mathrm{T}$ cell immunity and peripheral tolerance induction in vivo. Immunity 1, 327-339.

Kerdiles, Y. M., Beisner, D. R., Tinoco, R., Dejean, A. S., Castrillon, D. H., Depinho, R. A., et al. (2009). Foxol links homing and survival of naive $\mathrm{T}$ cells by regulating $\mathrm{L}$-selectin, CCR7 and interleukin 7 receptor. Nat. Immunol. 10, 176-184.

Kim, E. H., Sullivan, J. A., Plisch, E. H., Tejera, M. M., Jatzek, A., Choi, K. Y., et al. (2012). Signal integration by Akt regulates CD8 T cell effector and memory differentiation. J. Immunol. 188, 4305-4314.

Kim, H., Rafiuddin-Shah, M., Tu, H. C., Jeffers, J. R., Zambetti, G. P., Hsieh, J. J., et al. (2006). Hierarchical regulation of mitochondrion-dependent apoptosis by BCL-2 subfamilies. Nat. Cell Biol. 8, 1348-1358.

Klonowski, K. D., Williams, K. J., Marzo, A. L., and Lefrancois, L. (2006). Cutting edge: IL-7-independent regulation of IL-7 receptor alpha expression and memory CD8 $\mathrm{T}$ cell development. J. Immunol. 177, 4247-4251.

Kohlmeier, J. E., Reiley, W. W., PeronaWright, G., Freeman, M. L., Yager, E. J., Connor, L. M., et al. (2011). Inflammatory chemokine receptors regulate $\mathrm{CD} 8(+) \mathrm{T}$ cell contraction and memory generation following infection. J. Exp. Med. 208, 16211634.

Kurachi, M., Kurachi, J., Suenaga, F., Tsukui, T., Abe, J., Ueha, S., et al. (2011). Chemokine receptor CXCR3 facilitates CD8(+) $\mathrm{T}$ cell $\mathrm{T}$ cell differentiation into short-lived effector cells leading to memory degeneration. J. Exp. Med. 208, 1605-1620.

Kurtulus, S., Tripathi, P., MorenoFernandez, M. E., Sholl, A., Katz, J. D., Grimes, H. L., et al. (2011). Bcl2 allows effector and memory $\mathrm{CD}^{+}$ $\mathrm{T}$ cells to tolerate higher expression of Bim. J. Immunol. 186, 57295737.

Kuwana, T., Bouchier-Hayes, L., Chipuk, J. E., Bonzon, C., Sullivan, B. A., Green, D. R., et al. (2005). $\mathrm{BH} 3$ domains of $\mathrm{BH} 3$-only proteins differentially regulate Bax-mediated mitochondrial membrane permeabilization both directly and indirectly. Mol. Cell 17, 525-535.

Letai, A., Bassik, M. C., Walensky, L. D., Sorcinelli, M. D., Weiler, S., and Korsmeyer, S. J. (2002). Distinct BH3 domains either sensitize or activate mitochondrial apoptosis, serving as prototype cancer therapeutics. Cancer Cell 2, 183-192.

Link, A., Vogt, T. K., Favre, S., Britschgi, M. R., Acha-Orbea, H., Hinz, B., et al. (2007). Fibroblastic reticular cells in lymph nodes regulate the homeostasis of naive T cells. Nat. Immunol. 8 , 1255-1265.

Liu, F., and Whitton, J. L. (2005). Cutting edge: re-evaluating the in vivo cytokine responses of $\mathrm{CD}^{+} \mathrm{T}$ cells during primary and secondary viral infections. J. Immunol. 174, 59365940 .

Marshall, H. D., Chandele, A., Jung, Y. W., Meng, H., Poholek, A. C., Parish, I. A., et al. (2011). Differential expression of Ly6C and T-bet distinguish effector and memory Th1 CD4(+) cell properties during viral infection. Immunity 35, 633-646.

Martins, G. A., Cimmino, L., Liao, J., Magnusdottir, E., and Calame, K. (2008). Blimp-1 directly represses Il2 and the Il2 activator Fos, attenuating $\mathrm{T}$ cell proliferation and survival. J. Exp. Med. 205, 1959-1965.

Martins, G. A., Cimmino, L., ShapiroShelef, M., Szabolcs, M., Herron, A., Magnusdottir, E., et al. (2006). Transcriptional repressor Blimp-1 regulates $\mathrm{T}$ cell homeostasis and function. Nat. Immunol. 7, 457-465.

Marzo, A. L., Klonowski, K. D., Le Bon, A., Borrow, P., Tough, D. F., and Lefrancois, L. (2005). Initial T cell frequency dictates memory $\mathrm{CD} 8^{+} \mathrm{T}$ cell lineage commitment. Nat. Immunol. 6, 793-799.

Masopust, D., Ha, S. J., Vezys, V., and Ahmed, R. (2006). Stimulation history dictates memory CD8 $\mathrm{T}$ cell phenotype: implications for primeboost vaccination. J. Immunol. 177, 831-839.

Masopust, D., Vezys, V., Marzo, A. L., and Lefrancois, L. (2001). Preferential localization of effector memory cells in nonlymphoid tissue. Science 291, 2413-2417.

Miller, J. D., Van Der Most, R. G., Akondy, R. S., Glidewell, J. T., Albott, S., Masopust, D., et al. (2008). Human effector and memory CD8 ${ }^{+}$ $\mathrm{T}$ cell responses to smallpox and yellow fever vaccines. Immunity 28, 710-722.

Murali-Krishna, K., Altman, J. D., Suresh, M., Sourdive, D., Zajac, A., and Ahmed, R. (1998). In vivo dynamics of anti-viral CD8 T cell responses to different epitopes. An evaluation of bystander activation in primary and secondary responses to viral infection. Adv. Exp. Med. Biol. 452, 123-142.

Murphy, K. M., Travers, P., Walport, M., and Janeway, C. (2011). Janeway's 
Immunobiology. New York: Garland Science.

Murre, C. (2005). Helix-loop-helix proteins and lymphocyte development. Nat. Immunol. 6, 1079-1086.

Nakajima, H., Shores, E. W., Noguchi, M., and Leonard, W. J. (1997). The common cytokine receptor gamma chain plays an essential role in regulating lymphoid homeostasis. J. Exp. Med. 185, 189-195.

Nam, H. J., Song, M. Y., Choi, D. H., Yang, S. H., Jin, H. T., and Sung, Y. C. (2010). Marked enhancement of antigen-specific T-cell responses by IL-7-fused nonlytic, but not lytic, Fc as a genetic adjuvant. Eur. J. Immunol. 40, 351-358.

Nanjappa, S. G., Walent, J. H., Morre, M., and Suresh, M. (2008). Effects of IL-7 on memory CD8 T cell homeostasis are influenced by the timing of therapy in mice. J. Clin. Invest. 118 , 1027-1039.

Newell, E. W., Sigal, N., Bendall, S. C., Nolan, G. P., and Davis, M. M. (2012). Cytometry by time-of-flight shows combinatorial cytokine expression and virus-specific cell niches within a continuum of $\mathrm{CD}^{+} \mathrm{T}$ cell phenotypes. Immunity 36, 142-152.

Obar, J. J., Jellison, E. R., Sheridan, B. S., Blair, D. A., Pham, Q. M., Zickovich, J. M., et al. (2011). Pathogeninduced inflammatory environment controls effector and memory $\mathrm{CD} 8^{+}$ $\mathrm{T}$ cell differentiation. J. Immunol. 187, 4967-4978.

Obar, J. J., and Lefrancois, L. (2010). Early signals during CD8 T cell priming regulate the generation of central memory cells. J. Immunol. 185, 263-272.

Obar, J. J., Molloy, M. J., Jellison, E. R., Stoklasek, T. A., Zhang, W., Usherwood, E. J., et al. (2010). CD4 ${ }^{+} \mathrm{T}$ cell regulation of $\mathrm{CD} 25$ expression controls development of short-lived effector $\mathrm{CD}^{+} \mathrm{T}$ cells in primary and secondary responses. Proc. Natl. Acad. Sci. U.S.A. 107, 193-198.

Osborne, L. C., Dhanji, S., Snow, J. W., Priatel, J. J., Ma, M. C., Miners, M. J., et al. (2007). Impaired CD8 $\mathrm{T}$ cell memory and CD4 T cell primary responses in IL-7R alpha mutant mice. J. Exp. Med. 204, 619-631.

Pellegrini, M., Belz, G., Bouillet, P., and Strasser, A. (2003). Shutdown of an acute $\mathrm{T}$ cell immune response to viral infection is mediated by the proapoptotic Bcl-2 homology 3-only protein Bim. Proc. Natl. Acad. Sci. U.S.A. 100, 14175-14180.

Pellegrini, M., Calzascia, T., Toe, J. G., Preston, S. P., Lin, A. E., Elford, A. R., etal. (2011). IL-7 engages multiple mechanisms to overcome chronic viral infection and limit organ pathology. Cell 144, 601-613.

Pepper, M., Pagan, A. J., Igyarto, B. Z., Taylor, J. J., and Jenkins, M. K. (2011). Opposing signals from the Bcl6 transcription factor and the interleukin-2 receptor generate $\mathrm{T}$ helper 1 central and effector memory cells. Immunity 35, 583-595.

Petschner, F., Zimmerman, C., Strasser, A., Grillot, D., Nunez, G., and Pircher H. (1998). Constitutive expression of $\mathrm{Bcl}-\mathrm{xL}$ or $\mathrm{Bcl}-2$ prevents peptide antigen-induced $\mathrm{T}$ cell deletion but does not influence $\mathrm{T}$ cell homeostasis after a viral infection. Eur. J. Immunol. 28, 560-569.

Pircher, H., Moskophidis, D., Rohrer, U., Burki, K., Hengartner, H., and Zinkernagel, R. M. (1990). Viral escape by selection of cytotoxic T cellresistant virus variants in vivo. Nature 346, 629-633.

Plotkin, S. A., Orenstein, W. A., and Offit, P. A. (2008). Vaccines. Philadelphia: Saunders/Elsevier.

Prlic, M., and Bevan, M. J. (2008). Exploring regulatory mechanisms of $\mathrm{CD}^{+} \mathrm{T}$ cell contraction. Proc. Natl. Acad. Sci. U.S.A. 105, 16689-16694.

Prlic, M., and Bevan, M. J. (2011). Cutting edge: beta-catenin is dispensable for $\mathrm{T}$ cell effector differentiation, memory formation, and recall responses. J. Immunol. 187, 1542-1546.

Prlic, M., Hernandez-Hoyos, G., and Bevan, M. J. (2006). Duration of the initial TCR stimulus controls the magnitude but not functionality of the $\mathrm{CD}^{+} \mathrm{T}$ cell response. J. Exp. Med. 203, 2135-2143.

Rao, R. R., Li, Q., Gubbels Bupp, M. R., and Shrikant, P. A. (2012). Transcription factor Foxol represses $\mathrm{T}$ bet-mediated effector functions and promotes memory CD8(+) T cell differentiation. Immunity 36, 374-387.

Rao, R. R., Li, Q., Odunsi, K., and Shrikant, P. A. (2010). The mTOR kinase determines effector versus memory $\mathrm{CD}^{+} \mathrm{T}$ cell fate by regulating the expression of transcription factors T-bet and eomesodermin. Immunity 32, 67-78.

Rappuoli, R. (2007). Bridging the knowledge gaps in vaccine design. Nat. Biotechnol. 25, 1361-1366.

Reckling, S., Divanovic, S., Karp, C. L., Wojciechowski, S., Belkaid, Y., and Hildeman, D. (2008). Proapoptotic Bcl-2 family member Bim promotes persistent infection and limits protective immunity. Infect. Immun. 76, 1179-1185.

Reyes-Sandoval, A., Wyllie, D. H., Bauza, K., Milicic, A., Forbes, E. K.,
Rollier, C. S., et al. (2011). CD8 ${ }^{+} \mathrm{T}$ effector memory cells protect against liver-stage malaria. J. Immunol. 187, 1347-1357.

Rieux-Laucat, F., Le Deist, F., Hivroz, C., Roberts, I. A., Debatin, K. M., Fischer, A., et al. (1995). Mutations in Fas associated with human lymphoproliferative syndrome and autoimmunity. Science 268, 1347-1349.

Rubinstein, M. P., Lind, N. A., Purton, J. F., Filippou, P., Best, J. A., Mcghee, P. A., et al. (2008). IL-7 and IL-15 differentially regulate $\mathrm{CD} 8^{+} \mathrm{T}$ cell subsets during contraction of the immune response. Blood 112, 3704 3712.

Rutishauser, R. L., Martins, G. A., Kalachikov, S., Chandele, A., Parish, I. A., Meffre, E., et al. (2009). Transcriptional repressor Blimp-1 promotes CD8(+) T cell terminal differentiation and represses the acquisition of central memory $\mathrm{T}$ cell properties. Immunity 31, 296-308.

Sallusto, F., Lenig, D., Forster, R., Lipp, M., and Lanzavecchia, A. (1999). Two subsets of memory $\mathrm{T}$ lymphocytes with distinct homing potentials and effector functions. Nature 401, 708-712.

Sanjabi, S., Mosaheb, M. M., and Flavell, R. A. (2009). Opposing effects of TGF-beta and IL-15 cytokines control the number of short-lived effector $\mathrm{CD}^{+} \mathrm{T}$ cells. Immunity 31 , 131-144.

Sarkar, S., Kalia, V., Haining, W. N., Konieczny, B. T., Subramaniam, S. and Ahmed, R. (2008). Functional and genomic profiling of effector CD8 T cell subsets with distinct memory fates. J. Exp. Med. 205, 625-640.

Sarkar, S., Teichgraber, V., Kalia, V., Polley, A., Masopust, D., Harrington, L. E., et al. (2007). Strength of stimulus and clonal competition impact the rate of memory CD8 T cell differentiation. J. Immunol. 179, 6704-6714.

Schluns, K. S., Kieper, W. C., Jameson, S. C., and Lefrancois, L. (2000) Interleukin-7 mediates the homeostasis of naive and memory CD8 $\mathrm{T}$ cells in vivo. Nat. Immunol. 1 , 426-432.

Schluns, K. S., Williams, K., Ma, A., Zheng, X. X., and Lefrancois, L. (2002). Cutting edge: requirement for IL- 15 in the generation of primary and memory antigen-specific CD8 $\mathrm{T}$ cells. J. Immunol. 168, 4827-4831.

Stemberger, C., Huster, K. M., Koffler, M., Anderl, F., Schiemann, M., Wagner, H., et al. (2007). A single naive $\mathrm{CD}^{+} \mathrm{T}$ cell precursor can develop into diverse effector and memory subsets. Immunity 27, 985-997.
Strasser, A. (2005). The role of BH3only proteins in the immune system. Nat. Rev. Immunol. 5, 189-200.

Strasser, A., Harris, A. W., and Cory, S. (1991). bcl-2 transgene inhibits $\mathrm{T}$ cell death and perturbs thymic self-censorship. Cell 67, 889-899.

Sullivan, J. A., Kim, E. H., Plisch, E. H., Peng, S. L., and Suresh, M. (2012). FOXO3 regulates CD8 T cell memory by $\mathrm{T}$ cell-intrinsic mechanisms. PLoS Pathog. 8:e1002533. doi: 10.1371/journal.ppat.1002533

Takahashi, T., Tanaka, M., Brannan, C. I., Jenkins, N. A., Copeland, N. G., Suda, T., et al. (1994). Generalized lymphoproliferative disease in mice, caused by a point mutation in the Fas ligand. Cell 76, 969-976.

Thucydides, and Marchant, E. C. (1899). Thucydides, Book II. London: Macmillan.

Tripathi, P., Kurtulus, S., Wojciechowski, S., Sholl, A., Hoebe, K., Morris, S. C., et al. (2010). STAT5 is critical to maintain effector $\mathrm{CD}^{+}$ $\mathrm{T}$ cell responses. J. Immunol. 185, 2116-2124.

Tripathi, P., Mitchell, T. C., Finkelman, F., and Hildeman, D. A. (2007). Cutting Edge: limiting amounts of IL-7 do not control contraction of $\mathrm{CD}^{+}$ $\mathrm{T}$ cell responses. J. Immunol. 178 , 4027-4031.

Tunyaplin, C., Shaffer, A. L., AngelinDuclos, C. D., Yu, X., Staudt, L. M., and Calame, K. L. (2004). Direct repression of prdml by Bcl6 inhibits plasmacytic differentiation. J. Immunol. 173, 1158-1165.

van Stipdonk, M. J., Lemmens, E. E., and Schoenberger, S. P. (2001). Naive CTLs require a single brief period of antigenic stimulation for clonal expansion and differentiation. Nat. Immunol. 2, 423-429.

Vella, A., Teague, T. K., Ihle, J., Kappler, J., and Marrack, P. (1997). Interleukin 4 (IL-4) or IL-7 prevents the death of resting T cells: stat6 is probably not required for the effect of IL-4. J. Exp. Med. 186, 325-330.

Vella, A. T., Dow, S., Potter, T. A., Kappler, J., and Marrack, P. (1998). Cytokine-induced survival of activated $\mathrm{T}$ cells in vitro and in vivo. Proc. Natl. Acad. Sci. U.S.A. 95, 38103815.

Watanabe-Fukunaga, R., Brannan, C. I., Copeland, N. G., Jenkins, N. A., and Nagata, S. (1992). Lymphoproliferation disorder in mice explained by defects in Fas antigen that mediates apoptosis. Nature 356, 314-317.

Weinreich, M. A., Odumade, O. A., Jameson, S. C., and Hogquist, K. A. (2010). T cells expressing the 
transcription factor PLZF regulate the development of memory-like $\mathrm{CD}^{+} \mathrm{T}$ cells. Nat. Immunol. 11, 709-716.

Wherry, E. J., Teichgraber, V., Becker, T. C., Masopust, D., Kaech, S. M., Antia, R., et al. (2003). Lineage relationship and protective immunity of memory CD8 T cell subsets. Nat. Immunol. 4, 225-234.

Williams, M. A., and Bevan, M. J. (2007). Effector and memory CTL differentiation. Annu. Rev. Immunol. 25, 171-192.

Willis, S. N., Fletcher, J. I., Kaufmann, T., Van Delft, M. F., Chen, L., Czabotar, P. E., et al. (2007). Apoptosis initiated when $\mathrm{BH} 3$ ligands engage multiple Bcl-2 homologs, not Bax or Bak. Science 315, 856-859.

Wojciechowski, S., Jordan, M. B., Zhu, Y., White, J., Zajac, A. J., and
Hildeman, D. A. (2006). Bim mediates apoptosis of CD127(lo) effector T cells and limits T cell memory. Eur. J. Immunol. 36, 1694-1706.

Wojciechowski, S., Tripathi, P., Bourdeau, T., Acero, L., Grimes, H. L., Katz, J. D., et al. (2007). Bim/Bcl2 balance is critical for maintaining naive and memory $\mathrm{T}$ cell homeostasis. J. Exp. Med. 204, 1665 1675.

Yang, C. Y., Best, J. A., Knell, J., Yang, E., Sheridan, A. D., Jesionek, A. K., et al. (2011). The transcriptional regulators $\mathrm{Id} 2$ and $\mathrm{Id} 3$ control the formation of distinct memory $\mathrm{CD}^{+}$ $\mathrm{T}$ cell subsets. Nat. Immunol. 12, 1221-1229.

Youle, R. J., and Strasser, A. (2008). The BCL-2 protein family: opposing activities that mediate cell death. Nat. Rev. Mol. Cell Biol. 9, 47-59.
Zhou, X., Yu, S., Zhao, D. M., Harty, J. T., Badovinac, V. P., and Xue, H. H. (2010). Differentiation and persistence of memory CD8(+) T cells depend on $\mathrm{T}$ cell factor 1. Immunity 33, 229-240.

Zong, W. X., Lindsten, T., Ross, A. J. Macgregor, G. R., and Thompson, C. B. (2001). BH3-only proteins that bind pro-survival Bcl-2 family members fail to induce apoptosis in the absence of Bax and Bak. Genes Dev. 15, 1481-1486.

Conflict of Interest Statement: The authors declare that the research was conducted in the absence of any commercial or financial relationships that could be construed as a potential conflict of interest.
Received: 01 October 2012; paper pending published: 28 October 2012; accepted: 15 December 2012; published online: 23 January 2013.

Citation: Kurtulus S, Tripathi $P$ and Hildeman DA (2013) Protecting and rescuing the effectors: roles of differentiation and survival in the control of memory $T$ cell development. Front. Immun. 3:404. doi: 10.3389/fimmu.2012.00404

This article was submitted to Frontiers in Immunological Memory, a specialty of Frontiers in Immunology.

Copyright (c) 2013 Kurtulus, Tripathi and Hildeman. This is an open-access article distributed under the terms of the Creative Commons Attribution License, which permits use, distribution and reproduction in other forums, provided the original authors and source are credited and subject to any copyright notices concerning any third-party graphics etc. 